\title{
A "Modest" Proposal To Balance The Federal Budget
}

Robert B. Matthews, J.D., C.P.A., Sam Houston State University, USA

\begin{abstract}
The total debt of the United States (US) federal government now exceeds annual Gross Domestic Product (GDP). This level has historically proved problematic in other countries. The primary driver of the debt is a federal budget deficit that now exceeds \$1 trillion per year. Despite forecasts of dire consequences, the deficit and debt have not been controlled, as efforts to make meaningful reductions-including plans developed by the bipartisan Bowles-Simpson and Domenici-Rivlin groups - have so far fallen prey to infighting in the political process. This paper examines one approach to eliminate the annual deficit, balance the federal budget, and reduce the federal debt. This approach increases tax revenues with a flat income tax applied to a broader tax base plus a consumption tax. Health and welfare spending is reformed using the Boortz-Linder Prebate and the Bismarck social-insurance health care plan to provide a more comprehensive safety net. Defense spending is reduced by making greater use of reserve forces following the model of Sweden, Switzerland, and Israel, by reducing overseas deployments, and by reforming procurement. Many unnecessary or counterproductive activities are cancelled, transferred to the states, or privatized. Social security is placed on a sound footing for the future. These proposals are based in large part upon programs and procedures that have produced positive results in other countries. This approach is offered not as the only or best solution, but rather to indicate that solution is possible and to lead to further discussion.
\end{abstract}

Keywords: Balanced Budget; Bowles-Simpson; Bismarck Social Insurance; Boortz-Linder Prebate; Budget; Consumption Tax; Debt; Deficit; Domenici-Rivlin; Flat Tax; Gross Domestic Product (GDP), Income Tax; Military Spending; Overseas Deployments; Privatization; Procurement; Reserve Forces; Safety Net; Social Security; United States; Welfare Spending

(T)he best economic stimulus is fiscally responsible, long-term deficit reduction that sends a clear signal to the private sector about Washington's commitment to economic stability.

- Michael Bloomberg, Mayor of New York, 8 November 2011

Our national debt is our biggest national security threat.

- Admiral Mike Mullen, Chairman of the Joint Chiefs of Staff, 23 June 2010

\section{INTRODUCTION}

n September 2012 the total debt of the United States (US) federal government topped $\$ 16$ trillion, roughly equal to the US Gross Domestic Product (GDP), the value of all goods and services produced in the US in one year. Of this total, roughly $\$ 4.74$ trillion is inter-government and $\$ 11.27$ trillion is owed to outsiders. About $\$ 5.4$ trillion is owed to foreign investors, with about $\$ 1.1$ trillion each to Chinese and Japanese entities. The 2012 budget prepared by the Obama administration showed the debt increasing past $\$ 26$ trillion by 2022. Economist Mark Zandi of Moody's Analytics described reaching the $100 \%$ mark as an indication of "the grave need to address our long-term fiscal problems." (Woolf, 9 Jan 2012). The debt has grown to such level primarily because of continued annual budget deficits. Off-budget items affect the debt as well, but the budget deficit is the largest single factor.

There is some confusion in the general public about differentiating between deficits and the debt. They two are different, but are related as follows: 
Debt at beginning of year

$+\quad$ Deficit for this year, if applicable

- Surplus for this year, if applicable

+/- Off-budget items

$=$ Debt at end of year

Conceptually, it may be helpful to think in accounting terms that the debt is comparable to accumulated retained earnings on the balance sheet while the annual surplus or deficit is comparable to one year's net income or loss on the income statement. Another related misconception is the tendency, particularly among politicians, to commingle annual amounts with totals for multiple years. For example, it is a common political gambit to speak a $\$ 1$ trillion dollar deficit on the one hand and then promote a proposed solution with a claimed impact of $\$ 500$ billion, when the claimed impact actually represents 10 years of impact at $\$ 50$ billion per year. Obviously and misleadingly, the $\$ 500$ billion number implies a much more significant impact on the deficit than the proper annual amount of $\$ 50$ billion. A more truthful presentation would compare one year of impact to one year's deficit, or ten years of impact to ten years of projected deficits. But that more truthful presentation would obviously weaken the case for the proponent, who therefore engages in this sleight of hand. To avoid the latter issue, all amounts throughout this paper are expressed in terms of single year impact, unless specifically stated otherwise.

Figure 1 shows the growth in the federal debt compared to GDP for the period from 1940 to estimates for 2017 (source OMB, 2012).

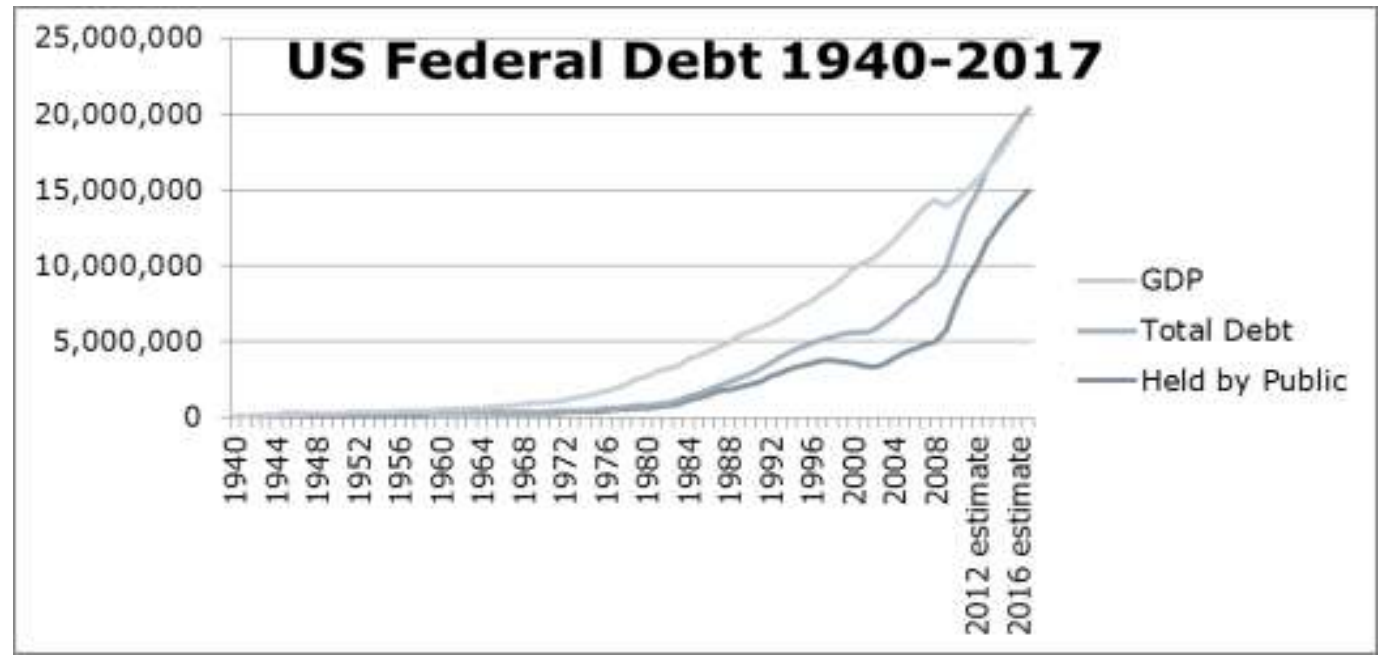

Figure 1 - Growth Of The Federal Debt 1940-2017

Total debt began to increase significantly in the mid 1970s, and continued to increase thereafter, but remained significantly lower than GDP until about 2008. Debt held by the public excludes certain borrowings from other governmental agencies or funds, such as the Social Security trust fund.

Figure 2 shows how revenues and expenditures, and the resulting surpluses and deficits, have contributed to the growth of the debt since 1940 (source OMB, 2012). Consistent with the growth of the debt in the comparable time frame, Figure 2 shows that throughout most of the period 1976-present, spending has exceeded 20\% of GDP while revenues have been less than $20 \%$ of GDP. 


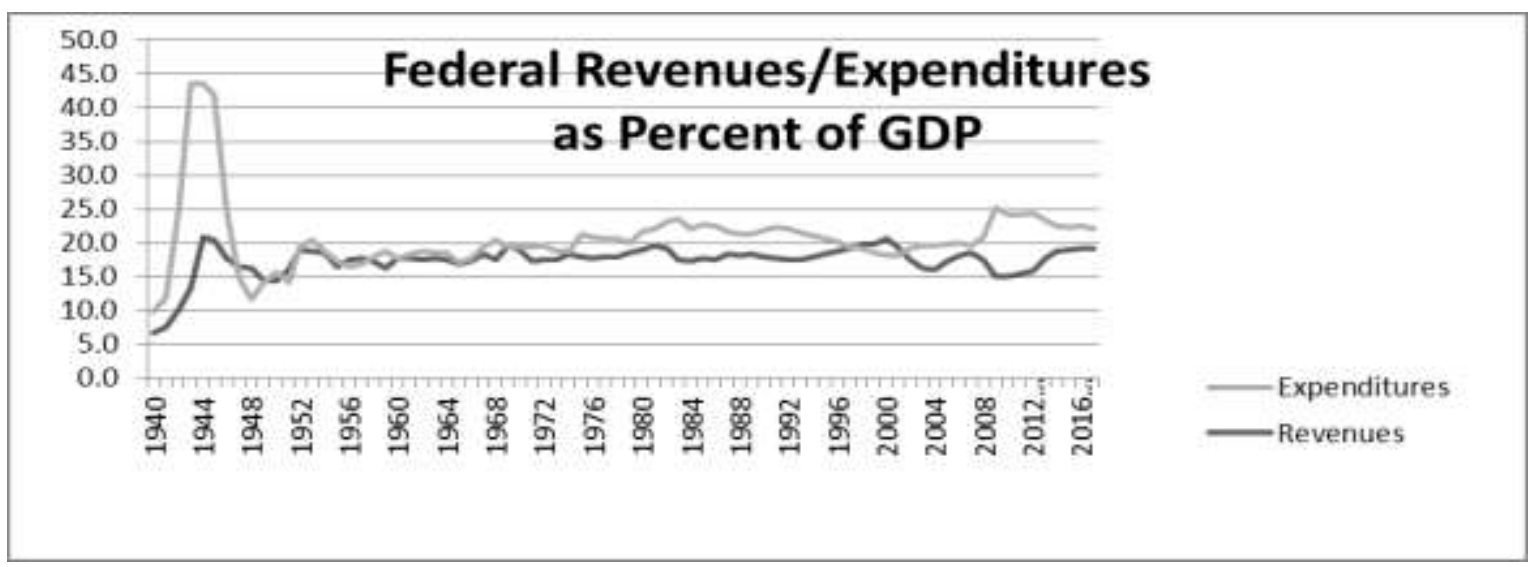

Figure 2 - Federal Revenues/Expenditures As A Percent Of GDP 1940-2017

Although each major political party is quick to blame the other, it should be noted that deficits are not a partisan issue. Deficits have been the rule with either Democrats or Republicans in power, in virtually any combination, as shown in Table 1, with dollar amounts in billions (OMB, 2012):

Table 1 - Debt And Deficit By Party Controlling Congress And Presidency

\begin{tabular}{|c|c|c|c|c|c|c|c|}
\hline \multirow{2}{*}{ Period } & \multicolumn{3}{|c|}{$\begin{array}{c}\text { Party controlling } \\
\text { (D=Democrat } / \mathrm{R}=\text { Republican) }\end{array}$} & \multirow{2}{*}{$\begin{array}{l}\text { Average } \\
\text { annual } \\
\text { budget } \\
\text { deficit } \\
\text { (surplus) }\end{array}$} & \multirow{2}{*}{$\begin{array}{c}\text { Average } \\
\text { annual } \\
\text { increase } \\
\text { (decrease) } \\
\text { in debt }\end{array}$} & \multirow{2}{*}{$\begin{array}{c}\text { Increase } \\
\text { (decrease) } \\
\text { in debt }\end{array}$} & \multirow{2}{*}{$\begin{array}{c}\text { Ending } \\
\text { debt }\end{array}$} \\
\hline & Presidency & Senate & House & & & & \\
\hline $1789-1980$ & Various & Various & Various & $\$ 9$ & $\$ 5$ & $\$ 994$ & $\$ 994$ \\
\hline $1981-86$ & $\mathrm{R}$ & $\mathrm{R}$ & $\mathrm{D}$ & 172 & 270 & 1,352 & 2,346 \\
\hline 1987-92 & $\mathrm{R}$ & $\mathrm{D}$ & $\mathrm{D}$ & 206 & 401 & 2,005 & 4,351 \\
\hline 1993-94 & $\mathrm{D}$ & $\mathrm{D}$ & $\mathrm{D}$ & 229 & 170 & 569 & 4,920 \\
\hline $1995-2000$ & $\mathrm{D}$ & $\mathrm{R}$ & $\mathrm{R}$ & (23) & 47 & 849 & 5,769 \\
\hline 2001-02 & $\mathrm{R}$ & $\mathrm{D}$ & $\mathrm{R}$ & 15 & 446 & 991 & 6,760 \\
\hline 2003-06 & $\mathrm{R}$ & $\mathrm{R}$ & $\mathrm{R}$ & 339 & 548 & 2,190 & 8,950 \\
\hline $2007-08$ & $\mathrm{R}$ & $\mathrm{D}$ & $\mathrm{D}$ & 936 & 1,463 & 2,926 & 11,876 \\
\hline $2009-10$ & $\mathrm{D}$ & $\mathrm{D}$ & $\mathrm{D}$ & 1,297 & 1,444 & 2,888 & 14,764 \\
\hline $2011-12$ & $\mathrm{D}$ & $\mathrm{D}$ & $\mathrm{R}$ & 1,114 & 1,392 & 2,784 & 17,548 \\
\hline
\end{tabular}

Note: For purposes of this table, party elected in year 1 and taking power in year 2 is deemed to be responsible for budgets in fiscal years (FY) 3 and 4. For example, results for 2001-02 reflect outcome of 2000 election, deficits for FY 2002 and FY 2003, and cumulative debs at the ends of FY 2003. Alternative interpretations yield results that vary slightly, but do not alter the conclusion materially. Annual budget deficits differ from annual change in the debt due to certain "off budget" items.

The budget deficit has exceeded $\$ 1$ trillion per year since 2008, and is expected to continue for the foreseeable future to exceed the amount of any annual deficit prior to 2008. Table 2 shows the projected debt and deficit numbers from President Obama's 2013 budget proposal (OMB, 2012, Historical Tables, Table 1-1 and Table 7-1, amounts in billions of dollars):

Table 2 - Projected Deficit And Debt Amounts

\begin{tabular}{|c|c|c|c|c|c|}
\hline Year & Receipts & Outlays & Surplus (Deficit) & Total Debt & Debt Held by Public \\
\hline 2012 & 2,469 & 3,796 & $(1,327)$ & 16,351 & 11,578 \\
\hline 2013 & 2,902 & 3,803 & $(901)$ & 17,548 & 12,637 \\
\hline 2014 & 3,216 & 3,883 & $(667)$ & 18,500 & 13,445 \\
\hline 2015 & 3,450 & 4,060 & $(610)$ & 19,427 & 14,197 \\
\hline 2016 & 3,680 & 4,329 & $(649)$ & 20,391 & 14,980 \\
\hline 2017 & 3,919 & 4,532 & $(613)$ & 21,325 & 15,713 \\
\hline
\end{tabular}

The 2012 budget included revenues of $\$ 2.6$ trillion, defense expenditures of $\$ 0.8$ trillion, other discretionary expenditures of $\$ 0.5$ trillion, mandatory expenditures of $\$ 2.3$ trillion, and interest expense of $\$ 0.2$ 
trillion, resulting in total expenditures of $\$ 3.8$ trillion and a deficit of $\$ 1.2$ trillion (OMB, 2012). The magnitude of those amounts clearly means:

- $\quad$ The proposal to increase personal income taxes on those making more than $\$ 250,000$, expected to produce $\$ 80$ billion per year, would have minimal effect on the deficit.

- $\quad$ Complete elimination of military spending would not be sufficient to eliminate the deficit, or even reduce it to pre-2008 levels.

- $\quad$ Elimination of all discretionary spending, both military and non-military, would eliminate the deficit, but barely so.

Therefore it is reasonable to conclude that elimination or significant reduction of the deficit will require increased revenues, reforms to entitlement programs to reduce mandatory spending, and reductions wherever possible in military and other discretionary spending. To this point, neither major political party-Democrats nor Republicans - has truly faced the problem. There has been more infighting than accomplishment (Smith and Cowan, 2011). Some minor compromise measures have been implemented, but nothing of sufficient scale to effect a material reduction of either deficit or debt. Republicans have opposed tax increases and cuts to military spending. Democrats have opposed cuts to welfare and entitlement spending. During the past two years, several different attempts have been made to find ways to reduce the large deficit and growing debt.

- The Bowles-Simpson Commission, appointed by President Obama, whose report was slated to be submitted to Congress for an up-or-down vote if $77 \%$ of its members had supported it (61\% did support it, including majorities of both Republicans and Democrats on the commission)

- $\quad$ The Rivlin-Domenici Committee, formed to develop an independent bipartisan plan

- $\quad$ President Obama's own budget proposal

- An alternative Republican proposal developed by Representative Paul Ryan

It should be noted that:

- $\quad$ Three of the four proposals actually reduce the top marginal tax rates for both individuals and corporations to enhance economic growth by increasing US competitiveness, making up revenues by broadening the tax base through reduction or elimination of deductions and exemptions.

- $\quad$ The Domenici-Rivlin plan accomplishes the maximum reduction in the debt to GDP ratio, primarily because it includes a consumption tax for the specific purpose of debt reduction.

- $\quad$ The Bowles-Simpson plan proposes the largest reduction in defense spending, while the Ryan plan proposes the largest reduction in domestic discretionary spending

Table 3 summarizes the principal points of those four proposals (dollar amounts in billions).

Table 3 - Principal Provisions Of Various Deficit Reduction Proposals

\begin{tabular}{|l|l|l|l|l|}
\hline \multicolumn{1}{|c|}{ Proposal/Author } & \multicolumn{1}{|c|}{ Bowles-Simpson } & \multicolumn{1}{c|}{ Domenici-Rivlin } & \multicolumn{1}{c|}{ President Obama } & Congressman Paul Ryan \\
\hline Origin & $\begin{array}{l}\text { Bipartisan, } \\
\text { commissioned by } \\
\text { President Obama }\end{array}$ & $\begin{array}{l}\text { Bipartisan Policy } \\
\text { Center }\end{array}$ & Democrat & Republican \\
\hline Debt to GDP in 2022 & $62 \%$ & $59 \%$ & $77 \%$ per budget & $70 \%$ \\
\hline $\begin{array}{l}\text { Domestic discretionary } \\
\text { savings }\end{array}$ & $\$ 680 \mathrm{~B}$ over 12 years & $\$ 440 \mathrm{~B}$ over 12 years & $\$ 770 \mathrm{~B}$ over 12 years & \$2,000B over 12 years \\
\hline Defense savings & $\$ 1,100 \mathrm{~B}$ over 12 years & $\$ 580 \mathrm{~B}$ over 12 years & \$400B over 12 years & \$78B over 12 years \\
\hline Other mandatory & Unspecified & Unspecified & \$360B over 12 years & $\$ 715 \mathrm{~B}$ over 12 years \\
\hline Individual tax rates & $12 \%-22 \%-28 \%$ & $15 \%-27 \%$ & Up to 39.6\% & Top annual rate $25 \%$ \\
\hline Corporate tax rates & $28 \%$ & $27 \%$ & Unspecified & $25 \%$ \\
\hline Other & $\begin{array}{l}\text { Approved by } 61 \% \text { of } \\
\text { commission, } \\
\text { including majorities } \\
\text { of both D and R. }\end{array}$ & $\begin{array}{l}\text { Includes } \\
\text { consumption tax. }\end{array}$ & $\begin{array}{l}\text { Only proposal that } \\
\text { does not reduce tax } \\
\text { rates. }\end{array}$ & \\
\hline
\end{tabular}


Comparing the US to other developed countries provides useful perspective for evaluating alternative approaches. Figure 3 (source OECD 2012) reflects total national, state/provincial, and local taxes and spending for the developed countries:

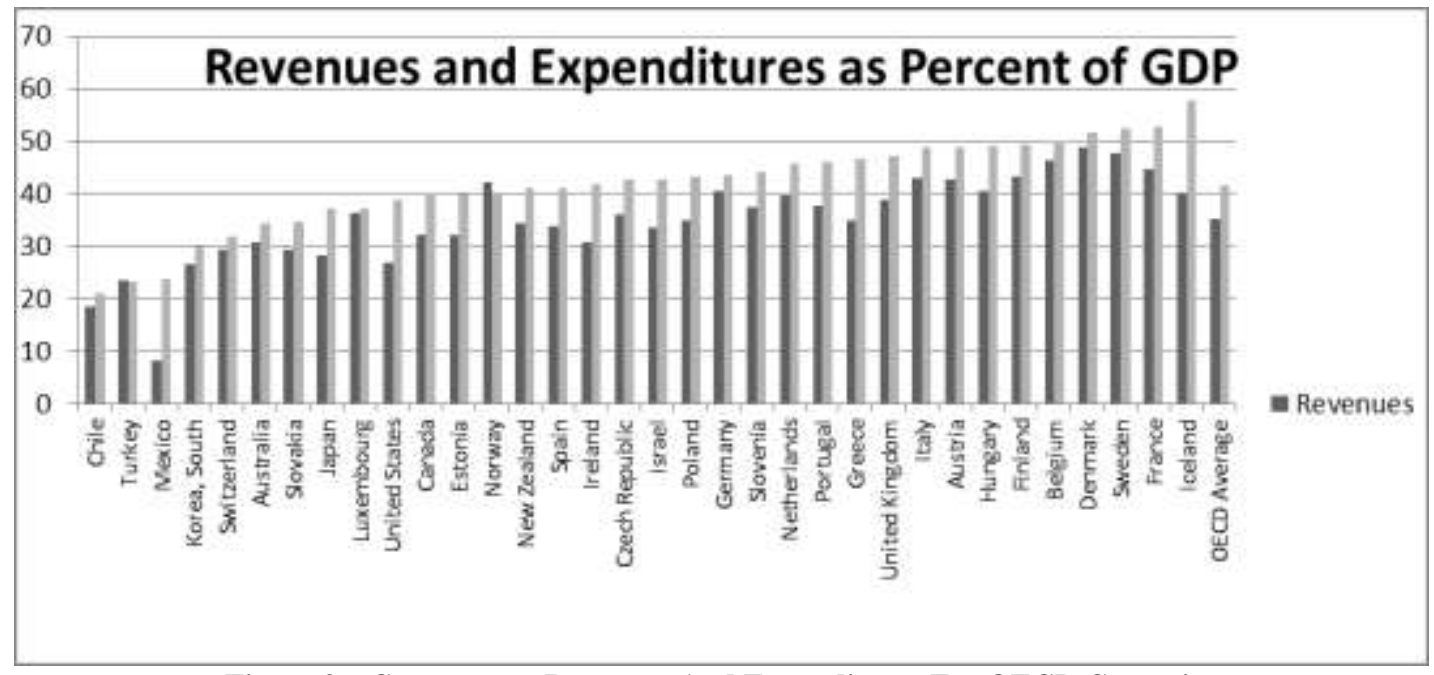

Figure 3 - Government Revenues And Expenditures For OECD Countries

Including federal, state, and local levels, US government expenditures are slightly below average for OECD. US government revenues are substantially less than OECD average, resulting in deficits and debt.

\section{OBJECTIVES}

The analysis described in this paper has been performed with the following goals/objectives in mind:

- $\quad$ Reduce annual deficit by $80-100 \%$

- $\quad$ Reduce accumulated debt from $100 \%$ to $60 \%$ of GDP in 10 years

- $\quad$ Make US more competitive in world markets to increase jobs and growth

- $\quad$ Maintain or improve welfare safety net

- $\quad$ Maintain strongest defense in world, tailored to threat scenario

- $\quad$ Provide for future solvency of social security

\section{METHODOLOGY AND ASSUMPTIONS}

This analysis has utilized the following methodology:

- $\quad$ Start from President Obama's proposed budget deficit of \$901 billion for 2013

- Use projections of economic growth, GDP, other activity from President's Budget for 2013

- $\quad$ Use historical tax data from IRS databases

- $\quad$ Calculate the components of taxable income by applying the GDP growth rates proposed in President Obama's 2013 budget to historical baseline data

- $\quad$ Calculate impact of tax changes by applying proposed rates and tax structure to projected levels of taxable income and other components of the tax base

- $\quad$ Use the 2013 projected amounts in President Obama's budget for 2012 as the baseline

- Where spending cuts have been proposed by other analysts, generally accept their calculations.

Significant assumptions include:

- $\quad$ GDP will grow as projected in the president's budget for 2013 
- Various components of taxable income will continue in proportion to GDP as they have been for the period 2005-2009.

- Interest rates on federal debt, compared to the projection in the president's budget for 2013, will be equal to the projected level in 2013, 0.25\% higher than the projected level in 2014, 0.5\% higher than the projected level for 2015, $0.75 \%$ higher than the projected level in 2016, and $1.0 \%$ higher than the projected level in 2016 and subsequently.

- $\quad$ Businesses and consumers will not modify their economic decisions from current projections as a result of changes in government tax and spending policies, although the expectation is that several modifications will in fact occur and that the net effect of such modifications will be decidedly positive.

Table 17 (at end) summarizes the key historic data used as the basis for the analysis and calculations.

\section{TAXES/REVENUES}

In evaluating various proposals to increase revenues, it is helpful to look first at how other countries generate tax revenues. Both Bowles-Simpson and Domenici-Rivlin noted a need to implement a tax structure that improves US competitiveness in the global economy. They cited this need as the primary reason for the approach they adopted - reducing tax rates, elimination or reduction of deductions, and generally broadening the tax base.

The Organisation for Economic Co-operation and Development (OECD) maintains tax databases for its member countries (which are essentially the developed countries of the world). Table 4 shows the sources of tax revenues for the developed countries as a whole, compared to the current US tax revenue sources, which can provide useful guidance regarding possible restructuring of tax structures to increase productivity (OECD, 2012, and GPO, 2012, Historical Tables, Table 2-1):

Table 4 - Comparative Tax Revenue Sources For US And OECD Countries

\begin{tabular}{|c|c|c|c|c|c|c|c|}
\hline \multirow[t]{2}{*}{ Source } & \multicolumn{6}{|c|}{ Tax Structures for the OECD Countries as a Whole } & \multirow{2}{*}{$\begin{array}{c}\text { US } \\
2009 \\
\end{array}$} \\
\hline & 1965 & 1975 & 1985 & 1995 & 2005 & 2009 & \\
\hline Personal income tax & $26 \%$ & $30 \%$ & $30 \%$ & $26 \%$ & $24 \%$ & $25 \%$ & $48 \%$ \\
\hline Corporate income tax & $9 \%$ & $8 \%$ & $8 \%$ & $8 \%$ & $10 \%$ & $8 \%$ & $11 \%$ \\
\hline Social security and other payroll taxes & $19 \%$ & $23 \%$ & $23 \%$ & $26 \%$ & $26 \%$ & $27 \%$ & $33 \%$ \\
\hline National property taxes & $8 \%$ & $6 \%$ & $5 \%$ & $5 \%$ & $6 \%$ & $5 \%$ & - \\
\hline General consumption taxes & $12 \%$ & $13 \%$ & $16 \%$ & $19 \%$ & $20 \%$ & $20 \%$ & - \\
\hline Specific consumption/ excise taxes & $24 \%$ & $18 \%$ & $16 \%$ & $13 \%$ & $11 \%$ & $11 \%$ & $2 \%$ \\
\hline Other taxes & $2 \%$ & $2 \%$ & $2 \%$ & $3 \%$ & $3 \%$ & $3 \%$ & $6 \%$ \\
\hline Total & $100 \%$ & $100 \%$ & $100 \%$ & $100 \%$ & $100 \%$ & $100 \%$ & $100 \%$ \\
\hline
\end{tabular}

The US tax structure is far more reliant on the individual income tax and somewhat more reliant on the corporate income tax and (highly regressive) social security tax than OECD as a whole. Unlike the rest of OECD, the US has no general consumption tax and relies far less on specific consumption and excise taxes than OECD as a whole.

In addition to the differences in tax sources, there are differences in comparing tax rate structures within each tax. Table 5 compares the top individual, corporate, and combined dividend (combination of corporate tax rate plus individual tax rate on after tax income returned as dividends) tax rates (including national, state, and local) for the US to the comparable average for all OECD countries, including a comparison of top marginal tax rates to total tax bite (total taxes divided by GDP) for both US and OECD (OECD, 2012): 
Table 5 - Comparative Tax Structures For US And OECD Countries

\begin{tabular}{|l|c|c|c|c|c|c|c|c|}
\hline \multirow{2}{*}{ Description } & \multicolumn{2}{|c|}{$\mathbf{1 9 9 5}$} & \multicolumn{2}{c|}{$\mathbf{2 0 0 0}$} & \multicolumn{2}{c|}{$\mathbf{2 0 0 5}$} & \multicolumn{2}{c|}{$\mathbf{2 0 1 0}$} \\
\cline { 2 - 8 } & US & OECD & US & OECD & US & OECD & US & OECD \\
\hline Personal/Individual taxes & & & & & & & & \\
\hline - Top marginal rate & $43.0 \%$ & $49.0 \%$ & $46.7 \%$ & $46.5 \%$ & $41.4 \%$ & $43.1 \%$ & $41.9 \%$ & $41.7 \%$ \\
\hline - Lowest marginal rate & N/A & N/A & $15.0 \%$ & $13.8 \%$ & $10.0 \%$ & $13.9 \%$ & $10.0 \%$ & $13.7 \%$ \\
\hline - Ratio & N/A & N/A & 3.1 & 3.4 & 4.1 & 3.1 & 4.2 & 3.0 \\
\hline Corporate taxes & & & & & & & & \\
\hline - Top marginal rate & $39.6 \%$ & $36.6 \%$ & $39.3 \%$ & $32.8 \%$ & $39.3 \%$ & $28.2 \%$ & $39.1 \%$ & $25.4 \%$ \\
\hline $\begin{array}{l}\text { Combined dividend tax } \\
\text { (CIT + PIT) }\end{array}$ & & & & & & & & \\
\hline - Top marginal rate & $67.4 \%$ & $53.3 \%$ & $67.3 \%$ & $49.0 \%$ & $52.0 \%$ & $43.2 \%$ & $52.2 \%$ & $41.4 \%$ \\
\hline Total overall tax bite & $27.8 \%$ & $34.5 \%$ & $29.5 \%$ & $35.2 \%$ & $27.1 \%$ & $34.9 \%$ & $24.8 \%$ & $33.8 \%$ \\
\hline $\begin{array}{l}\text { Ratio of top rate to total } \\
\text { tax bite }\end{array}$ & & & & & & & & \\
\hline - For individuals & 1.55 & 1.42 & 1.58 & 1.32 & 1.53 & 1.23 & 1.69 & 1.23 \\
\hline - For corporations & 1.42 & 1.06 & 1.33 & 0.93 & 1.44 & 0.81 & 1.58 & 0.75 \\
\hline - For dividends & 2.42 & 1.54 & 2.28 & 1.39 & 1.92 & 1.24 & 2.10 & 1.22 \\
\hline
\end{tabular}

This comparison strongly suggests that US taxes are substantially more progressive than for OECD as a whole, and more detailed analysis reveals the following points, some of them perhaps surprising:

- $\quad$ OECD top personal tax rates are slightly lower on average than the top US personal tax rates.

- $\quad$ OECD individual tax structures are generally less progressive than in the US, with the ratio of highest to lowest tax bracket approximately 4.2 to 1 in the US versus 3.0 to 1 for OECD.

- $\quad$ Both US and OECD individual tax rates have been trending lower since 2000, with the US structure becoming more progressive and OECD less progressive, as measured by the ratio of top rate to lowest rate.

- $\quad$ US corporate tax rates are substantially higher than the OECD average (and are currently highest in OECD), primarily because OECD corporate tax rates have fallen significantly since 1995 while US corporate rates have remained steady.

- $\quad$ The US combined dividend tax (the measure of the corporate tax bite plus individual tax bite on corporate earnings paid out as dividends) has been falling since 1995 but is substantially higher than the OECD average, currently ranking third highest in OECD.

Any discussion of "fair share" should thus consider that the US currently has a highly progressive tax system, the most progressive in the developed world. In 2008, the percentage of total income, percentage of tax liability, and effective tax rates for the quintiles of individual taxpayers were as shown in Table 6 (Mencarow, 2011, quoting Gaver, 2010):

Table 6 - Shares Of Individual Income And Tax Liability By Quintile For 2008

\begin{tabular}{|l|c|c|c|c|c|c|c|}
\hline Quintile & $\begin{array}{c}\text { Number } \\
\text { (thousands) }\end{array}$ & $\begin{array}{c}\text { Income } \\
\text { (millions) }\end{array}$ & $\begin{array}{c}\text { Taxes paid } \\
\text { (millions) }\end{array}$ & \% Income & \% Taxes & $\begin{array}{c}\text { Effective } \\
\text { Tax Rate }\end{array}$ & $\begin{array}{c}\text { Ratio of \% } \\
\text { Taxes to \% } \\
\text { Income }\end{array}$ \\
\hline All & 139,960 & $8,426,625$ & $1,031,512$ & $100.0 \%$ & $100.0 \%$ & $12.2 \%$ & \\
\hline Top 1\% & 1,400 & $1,685,472$ & 392,149 & $20.0 \%$ & $38.0 \%$ & $23.3 \%$ & 1.90 \\
\hline Top 5\% & 6,998 & $2,926,701$ & 605,718 & $34.7 \%$ & $58.7 \%$ & $20.7 \%$ & 1.69 \\
\hline Top 10\% & 13,996 & $3,856,462$ & 721,421 & $45.8 \%$ & $69.9 \%$ & $18.7 \%$ & 1.53 \\
\hline Top 25\% & 34,990 & $5,678,179$ & 890,614 & $67.4 \%$ & $86.3 \%$ & $15.7 \%$ & 1.28 \\
\hline Top 50\% & 69,980 & $7,352,111$ & $1,003,639$ & $87.2 \%$ & $97.3 \%$ & $13.7 \%$ & 1.12 \\
\hline Bottom 50\% & 69,980 & $1,074,514$ & 27,873 & $12.8 \%$ & $2.7 \%$ & $2.6 \%$ & 0.21 \\
\hline
\end{tabular}

Interestingly Gaver (2010) also notes that the ratio of taxes to income was lower for the top quintile during the Clinton administration than during the George W. Bush administration, despite the "Bush tax cuts." 
Another perspective is provided by OECD (2008), which compared the concentration of household taxes to the concentration of income, using two approaches - one based on the Gini coefficient and the other based on the percentage share of income and taxes for the top $10 \%$ or incomes, with results comparing the US to selected countries and to OECD as a whole in Table 7 (note, results for countries omitted to save space are consistent with those presented). In the Gini comparison columns, a higher coefficient for taxes means that taxes are imposed more unequally on higher incomes, a higher coefficient for market income means that income is distributed more unequally in favor of higher incomes, and a larger ratio means that taxes are imposed more unequally than income is distributed. The percent share for the richest decile simply compares the share of taxes paid by the top decile (10\%) to the share of income for the top decile. In both analyses, a ratio greater than 1.00 means that taxes are imposed at greater than a pro rata rate on higher income, or in other words a more progressive tax structure.

Table 7 - "Fair Share" Calculation For Us Compared To OECD Countries

\begin{tabular}{|c|c|c|c|c|c|c|}
\hline \multirow[b]{2}{*}{ Country } & \multicolumn{3}{|c|}{ Concentration of household taxes and market income } & \multicolumn{3}{|c|}{ Percentage share of richest decile } \\
\hline & $\begin{array}{l}\text { Concentration } \\
\text { coefficient for } \\
\text { household taxes }\end{array}$ & $\begin{array}{c}\text { Gini } \\
\text { coefficient of } \\
\text { market } \\
\text { income }\end{array}$ & $\begin{array}{c}\text { Ratio of } \\
\text { concentration } \\
\text { coefficients to } \\
\text { Gini coefficients }\end{array}$ & $\begin{array}{c}\text { Share of } \\
\text { taxes of } \\
\text { richest } \\
\text { decile }\end{array}$ & $\begin{array}{c}\text { Share of } \\
\text { market } \\
\text { income of } \\
\text { richest decile }\end{array}$ & $\begin{array}{l}\text { Ratio of share of } \\
\text { taxes to share of } \\
\text { income for } \\
\text { richest decile }\end{array}$ \\
\hline Australia & 0.53 & 0.46 & 1.16 & 36.8 & 28.6 & 1.29 \\
\hline Canada & 0.49 & 0.44 & 1.13 & 35.8 & 29.3 & 1.22 \\
\hline France & 0.37 & 0.48 & 0.77 & 28.0 & 25.5 & 1.10 \\
\hline Germany & 0.47 & 0.51 & 0.92 & 31.2 & 29.2 & 1.07 \\
\hline Italy & 0.55 & 0.56 & 0.98 & 42.2 & 35.8 & 1.18 \\
\hline Japan & 0.38 & 0.44 & 0.85 & 28.5 & 28.1 & 1.01 \\
\hline Sweden & 0.34 & 0.43 & 0.78 & 26.7 & 26.6 & 1.00 \\
\hline Switzerland & 0.22 & 0.35 & 0.63 & 20.9 & 23.5 & 0.89 \\
\hline UK & 0.53 & 0.46 & 1.16 & 38.6 & 32.3 & 1.20 \\
\hline US & 0.59 & 0.46 & 1.28 & 45.1 & 33.5 & 1.35 \\
\hline OECD Average & 0.43 & 0.45 & 0.96 & 31.6 & 28.4 & 1.11 \\
\hline
\end{tabular}

By both measures, the US has a more progressive tax structure than OECD as a whole, and more progressive than any other OECD member country. OECD (2008) concluded that the US had the most progressive tax system in the world. It should be noted that based upon either the Gini measure or the share of market income measure, there is no strong correlation between more progressive tax structures and more even distribution of income. This may be because, as OECD further notes, while most countries rely more on cash transfers than taxes to redistribute income, the US stands out as attempting to achieve greater redistribution through the tax system than through cash transfers (OECD, 2008).

Some analysts have suggested that tax structures make other countries more attractive to investors than the US. It is certainly well documented that US individuals and companies (Mitt Romney, GE, Google, and Facebook) are investing and conducting business in foreign locations to reduce their tax bills. Bowles-Simpson and DomeniciRivlin noted this, and restructured US tax rates as discussed above to try to make the US more competitive again.

One driver behind the data for other OECD countries is the recent trend-particularly among developing nations seeking to increase both the growth of their economies and the efficiency of their taxation regimes - to abolish complex and loophole-filled progressive income tax systems and replace them with flatter and simpler taxes applied to broader tax bases. Particularly intriguing are the former communist countries, which have adopted this approach to promote growth in creating market economies from scratch-Estonia, Latvia, Lithuania, Russia, Slovakia, Serbia, Ukraine, Romania, and Georgia (Boortz, 2008, pp. 48-49).

This proposal incorporates a tax system that would adopt some of the taxation principles identified in other countries, as noted above, and would carry them further in an effort to increase US competitiveness in the worldwide economy. This 15-15-15 Plan includes the following elements:

- $\quad 15 \%$ payroll tax, which would work like current social security (7.5\% paid by employee, $7.5 \%$ paid by employer), but with the regressive income cap removed, and proceeds would go to the social security fund. 
- $15 \%$ flat tax on all business earnings regardless of form of entity - corporation (with deduction for dividends paid), partnership, LLC, farm, rental - and on all investment income - dividends, interest, capital gains

- $\quad 15 \%$ consumption tax - like "Fair Tax" or value-added tax (VAT) or general sales tax (GST).

This approach eliminates the personal income tax and the dreaded April 15 deadline. Unlike the "Fair Tax" proposal, the IRS would not be dismantled, but its role would shift significantly. All compliance work could be performed at the business entity level, reducing the number of taxable units from 140 million to 35 million, thereby facilitating more efficient audit coverage and increasing compliance. The IRS could also administer the Prebate (discussed below).

The payroll tax would work essentially like social security today, with the elimination of the wage and salary cap that makes the social security tax perhaps the most regressive in the entire US tax system. It would fund a comprehensive social security system, into which unemployment and disability income would be combined, as is done in France and other European countries. . Numerous studies have indicated that raising or eliminating the salary cap would significantly lengthen the time before the social security fund becomes insolvent. Social security is discussed in greater detail below.

The consumption tax effectively replaces the individual income tax, along the lines of the "Fair Tax" proposed by some more conservative groups.

The third leg is a flat rate $15 \%$ income tax on all business and investment activities-corporations, partnerships, limited liability companies, dividends (which would be deductible by the paying corporation), interest, capital gains, and rental and farm income. Because there is no personal income tax other than the payroll tax, this provision catches all non-payroll forms of income.

The consumption tax, combined with the flat business income tax, would reduce or eliminate current tax disincentives that chase investment overseas. A consumption tax can imposed on all imports, which effectively affords some tariff protection, and can be rebated on all exports, allowing other countries to "subsidize" exports. Rebates of consumption taxes (but not other taxes) are perfectly legal under international tax and tariff agreements to which the US is a party. Because the US is the only developed country that does not have a national consumption tax, its ability to tax imports is reduced and it is the only developed country that cannot rebate embedded taxes on exports, placing US companies at a significant disadvantage in the global economy. Principal beneficiaries would be the middle class, whose job prospects are enhanced. As will be shown below, the middle class also benefit because the medical benefits (as in Europe) and the Prebate (which Europe does not have) also accrue to the middle class.

Revenues from this tax structure have been based upon historic tax return data regarding salaries and wages and business income, projected into the future by applying the historic percentage of GDP to the GDP projections contained in President Obama's 2013 Budget (OMB, 2012). Estimation of revenues from the consumption tax requires some assumption regarding size of the tax base, and this has been a hotly debated topic. The proposed tax follows the "Fair Tax" approach of applying to all retail sales, and if the tax is structured alternatively as a value added tax (VAT), the same ultimate tax base would be proposed. Bachman, et al (2006) estimated that such a tax would apply to $81 \%$ of GDP. Gale (2006) noted correctly that most European VAT structures capture significantly less of GDP in the tax base (around 40\%) and calculated a consumption tax base of 70\% of GDP. Dale (1998), in response to Gale (1998), noted that Gale had failed to include in his tax base all transactions that "Fair Tax" would include, and calculated that the base would be $84 \%$ of GDP. Tuerck (2007) calculated a base equal to $81 \%$ of GDP. All differences appear to result from relatively minor disagreements over what should/should not be included in the consumption tax base. A base equal to $75 \%$ of GDP has been assumed in these calculations.

Flat tax and consumption tax schemes are frequently criticized as providing windfalls for higher incomes and penalizing lower incomes. First, for the effect on lower incomes, the Boortz-Linder Prebate (Prebate) makes this approach more progressive. The Prebate is essentially Milton Friedman's (1962) negative income tax adapted to a consumption tax environment. The Prebate is an amount paid to every family/taxable unit every month, determined as follows: 
- $\quad$ For each taxable unit (individual, family), determine the poverty level of income

- Provide a credit equal to $30 \%$ of that amount (to offset $15 \%$ payroll/business profit tax plus $15 \%$ consumption tax)

- $\quad$ Prebate the amount with a monthly check/EFT

Table 8 shows the Prebate calculation in accordance with the above formula:

Table 8 - Calculation Of Prebate Amounts For Specific Family Situations

\begin{tabular}{|c|c|c|c|c|c|c|c|c|}
\hline \multicolumn{4}{|c|}{ One adult household } & \multicolumn{4}{c|}{ Two adult household } \\
\hline Family Size & $\begin{array}{c}\text { Annual } \\
\text { Consumptio } \\
\text { n Allowance }\end{array}$ & $\begin{array}{c}\text { Annual } \\
\text { Prebate }\end{array}$ & $\begin{array}{c}\text { Monthly } \\
\text { Payment }\end{array}$ & Family Size & $\begin{array}{c}\text { Annual } \\
\text { Consumptio } \\
\text { n Allowance }\end{array}$ & $\begin{array}{c}\text { Annual } \\
\text { Prebate }\end{array}$ & $\begin{array}{c}\text { Monthly } \\
\text { Payment }\end{array}$ \\
\hline Single person & 11640 & 3492 & 291 & & Couple & 23279 & 6984 & 582 \\
\hline+1 child & 15659 & 4698 & 392 & & +1 child & 27299 & 8190 & 683 \\
\hline+2 & 19679 & 5904 & 492 & +2 & 31319 & 9396 & 783 \\
\hline+3 & 23699 & 7110 & 593 & +3 & 35338 & 10601 & 883 \\
\hline+4 & 27718 & 8315 & 693 & & +4 & 39358 & 11807 & 984 \\
\hline+5 & 31738 & 9521 & 793 & & +5 & 43378 & 13013 & 1084 \\
\hline+6 & 34683 & 10405 & 867 & & +6 & 47397 & 14219 & 1185 \\
\hline+7 & 39777 & 11933 & 994 & & +7 & 51417 & 15425 & 1285 \\
\hline
\end{tabular}

Table 9 calculates the total annual cost of the Prebate for 2013, based upon the on number of 1040 returns filed per IRS and demographic data per BLS.

Table 9 - Estimated Annual Cost Of Prebate

\begin{tabular}{|l|r|r|r|r|r|r|r|}
\hline & $\begin{array}{c}\text { Households } \\
\text { (thousands) }\end{array}$ & $\begin{array}{c}\text { Annual } \\
\text { Prebate }\end{array}$ & $\begin{array}{c}\text { Annual Cost } \\
\text { (thousands) }\end{array}$ & & $\begin{array}{c}\text { Households } \\
\text { (thousands) }\end{array}$ & $\begin{array}{c}\text { Annual } \\
\text { Prebate }\end{array}$ & $\begin{array}{c}\text { Annual Cost } \\
\text { (thousands) }\end{array}$ \\
\hline Single person & 30,837 & 3,492 & $107,682,804$ & Couple & 25,810 & 6,984 & $180,257,040$ \\
\hline and 1 child & 13,136 & 4,698 & $61,712,928$ & and 1 child & 11,866 & 8,190 & $97,182,540$ \\
\hline and 2 children & 6,863 & 5,904 & $40,519,152$ & and 2 children & 13,406 & 9,396 & $125,962,776$ \\
\hline and 3 children & 3,339 & 7,110 & $23,740,290$ & and 3 children & 5,964 & 10,601 & $63,224,364$ \\
\hline and 4 children & 1,488 & 8,315 & $12,372,720$ & and 4 children & 2,075 & 11,807 & $24,499,525$ \\
\hline and 5 children & 505 & 9,521 & $4,808,105$ & and 5 children & 620 & 13,013 & $8,068,060$ \\
\hline and 6 children & 305 & 10,405 & $3,173,525$ & and 6 children & 310 & 14,219 & $4,407,890$ \\
\hline and 7 children & 104 & 11,933 & $1,241,032$ & and 7 children & 109 & 15,425 & $1,681,325$ \\
\hline Subtotals & & & $255,250,556$ & & & & $505,283,520$ \\
\hline Total & & & & & & & $760,534,076$ \\
\hline
\end{tabular}

Second, we will look at the impact on upper incomes. Recently there have been a number of highlypublicized cases of high-income individuals paying effective tax rates as low as 14\%--for example, Mitt Romney $13.9 \%$ (Romney 2012) — and multiple analyses indicate that effective taxes on higher incomes average in the 20$25 \%$ range. Under this plan those individuals would pay a $15 \%$ payroll tax on income taken as salaries (those who own their businesses would pay both the employer and employee portions), or a $15 \%$ tax on business profits and investment gains, plus a $15 \%$ tax on their consumption. This makes their effective rates $22.5 \%$ if their consumption equals $50 \%$ of total income, $24.0 \%$ if they consume $60 \%$, and $25.5 \%$ if they consume $70 \%$, roughly comparable to or higher than current effective tax rates. Note that under this approach, the top incomes also receive medical benefits (as in Europe) and the Prebate, but those amounts are clearly immaterial with incomes at $\$ 1$ million or more.

One additional tax is proposed. Our dependence on oil causes economic, foreign policy, and environmental problems that have been well documented. A measure that would provide disincentive to use oil and other fossil fuels, as well as to raise revenues, would be useful. There are two basic approaches, the "cap and trade" plan or a carbon tax. This paper proposes imposing a carbon tax —an additional motor fuel tax of $\$ 2 /$ gallon, phased in 25 cents per year for 8 years. To mitigate the impact on lower incomes, this approach would provide an allowance of 10,000 miles per driver/vehicle per year, at the CAFE mileage standard, and include a monthly allowance in the 
Prebate. If the CAFE standard were $25 \mathrm{mpg}$, for example, then the allowance would be 400 gallons per year, and the tax on that amount would be included in the Prebate. At current usage of 13 million barrels of gasoline per day, or about 550,000 gallons per day, such a tax when fully implemented would provide approximately $\$ 399$ billion per year in additional revenues. The usage allowance of 10,000 miles per vehicle/driver pre year would cost approximately $\$ 138$ billion per year, for net revenue increase of $\$ 261$ billion when fully implemented. This would be phased in over 8 years, so if started in 2013 would not be fully implemented until 2020. Such a carbon tax could, and arguably should, be extended to other carbon fuel sources, but only the impact upon gasoline has been considered in this paper. Alternatively, a "cap and trade" scheme could be adopted.

Table 10 summarizes the impacts of these tax changes. Because some of them would be phased in, the single year impact when fully phased in is presented (in 2013 dollars) along with the phase-in results over 1, 5, and 10 years. Note that the cumulative totals may differ from 1, 5, or 10 times the proposed annual impact because phasing in would reduce the long-term impact while growth and inflation would increase it.

Table 10 - Impact Of Proposed Tax Changes

\begin{tabular}{|c|c|c|c|c|c|c|}
\hline \multirow[b]{2}{*}{ Tax (Amounts in \$ Billions) } & \multirow{2}{*}{$\begin{array}{c}\text { Per President } \\
\text { Obama's } \\
2013 \text { Budget }\end{array}$} & \multirow{2}{*}{$\begin{array}{c}\text { Proposed } \\
\text { Approach } \\
\text { for } 2013\end{array}$} & \multirow{2}{*}{$\begin{array}{c}\text { Annual } \\
\text { Impact } \\
(2013 \\
\text { dollars }) \\
\end{array}$} & \multicolumn{3}{|c|}{ Estimated Cumulative Impact } \\
\hline & & & & 1 year & 5 years & 10 years \\
\hline Individual income tax & 1,294 & 0 & $-1,294$ & $-1,294$ & $-7,588$ & $-18,304$ \\
\hline $\begin{array}{l}\text { Business/corporate/investment } \\
\text { income tax }\end{array}$ & 365 & 758 & 393 & 393 & 2,182 & 5,236 \\
\hline Payroll taxes & 990 & 1,008 & 18 & 13 & 124 & 206 \\
\hline Consumption tax & 0 & 1,985 & 1,985 & 1,838 & 10,272 & 23,455 \\
\hline Less Prebate & 0 & -839 & -839 & -839 & $-4,509$ & $-9,874$ \\
\hline $\begin{array}{l}\text { Additional carbon tax on gasoline } \\
\text { usage }\end{array}$ & 0 & 261 & 261 & 33 & 489 & 1,636 \\
\hline Other taxes & 253 & 253 & 0 & 0 & 0 & 0 \\
\hline Total taxes & 2,902 & 3,426 & 524 & 144 & 970 & 2,415 \\
\hline
\end{tabular}

\section{HEALTH, EDUCATION, AND WELFARE SPENDING}

The Patient Protection and Affordable Care Act (PPACA, or ACA, or Obamacare) had the following as its enumerated objectives:

- $\quad$ Provide universal health insurance

- $\quad$ Reduce the cost of health care

- $\quad$ Relieve the health care burden on US employers

It would appear to fail on all counts. It is now estimated that some 30 million people will be left without insurance through 2022 (Burke 2012, Elmendorf 2012). The Congressional Budget Office (CBO) has expressed skepticism about the ability of ACA to reduce or restrain costs without serious degradation of quality or availability (Elmendorf, 18 Nov 2009, p. 17), numerous analyses subsequent to passage appear to suggest that the negative impact on the federal budget will be greater than anticipated, and the incremental costs to states and the private sector appear to exceed the benefit to the federal government (Elmendorf, 19 Dec 2009, p. 20). With the penalty provisions for employers who fail to provide insurance coverage for employees, or who provided coverage that does not meet mandatory standards, the widespread perception in the business community is that ACA will make health care more expensive, not less, for businesses. This has led many businesses to seek exemptions, and many others to consider dropping health care coverage altogether. Taken together, these points would suggest consideration of another alternative.

One item cited in support of a change to US health care is the 2000 World Health Organization (WHO) study of world health care systems where the US health care system ranked $37^{\text {th }}$ (WHO, 2000). In reviewing the results of that study, several factors must be considered (WHO, 2000): 
- $\quad$ The WHO study evaluated not only quality but also cost and equality of access, and the factors were weighted roughly $20 \%$ quality, $40 \%$ cost, and $40 \%$ access. The US actually placed first in one of the two component measures that approximated quality, and $10^{\text {th }}$ in quality and access combined.

- $\quad$ The two systems commonly touted as models for the US to apply, Canada (single payer) and UK (single provider), ranked $30^{\text {th }}$ and $18^{\text {th }}$, respectively; particularly considering the heavy factor weightings given to access and cost, these represent very poor results versus the US.

- $\quad$ The methodology contained apparent bias in favor of smaller systems, as Andorra, San Marino, Malta, and Singapore placed in the top ten and Monaco was $13^{\text {th }}$. The US actually ranked first among countries with over 125 million in population, second (behind Japan, a Bismarck universal insurance system) among countries with over 85 million populations, and fourth (behind France, which ranked first overall, and Germany, both Bismarck universal insurance systems) among countries with over 65 million population.

In subsequent studies, systems utilizing the Bismarck universal insurance approach to health care tend pretty consistently to lead the pack, and have consistently outperformed UK and Canada in numerous studies with various metrics (Matthews, 2010). The approach to health care recommended herein is a version of the Bismarck approach, with three basic elements:

- $\quad$ Universal private health insurance

- $\quad$ Taxpayer funding for basic health insurance for all persons

- $\quad$ Freedom to supplement above the base, on either an individual or group (employer provided or otherwise) basis

In this system, government would function very much like an employer in the current US model, purchasing a basic health insurance policy for everyone, funded with consumption taxes. Everyone would then be able to supplement as wanted, and employers can supplement as an employee benefit. It is a model somewhat like Medicare. This approach breaks the US connection of health care to employment. With basic insurance paid by consumption taxes, the cost to an employer to provide supplemental insurance decreases considerably, further aiding global competitiveness. The market for health insurance above the baseline plan can be freer than the current US health insurance market, with many more options than are currently available. In France, for example, the vast majority of individuals do take advantage of this free market to supplement and the majority of businesses offer supplemental plans. In particular, this approach can restore the use of Health Spending Accounts (HSAs), which have been severely constrained under ACA/Obamacare. This is an important change because many analyses have indicated that the consumer control achieved with HSAs can have a major impact on controlling costs.

As for the cost of such a system, start by assuming an annual cost of $\$ 2,700 /$ person for the basic plan, which approximates the current French experience. For a population of 315 million people, that results in a cost of roughly $\$ 850$ billion. Assuming additionally that administrative costs are 10\% (Medicare currently experiences 5$7 \%$ administrative costs, for comparison), results in a total cost of $\$ 935$ billion. This cost of can be financed as follows:

- With this system, Medicaid becomes redundant and can be eliminated, saving $\$ 350$ billion at the federal level (OMB, 2012) and another \$125 billion at the state level (Urban Institute, 21 December 2011).

- $\quad$ The basic plan subsidizes 50 million people on Medicare to the extent of $\$ 2,700$ each per year, or $\$ 135$ billion in total, generating that amount of annual Medicare savings.

- With the impact of the Prefund, many people will no longer qualify for benefits under the current "meanstested" social welfare programs, and costs will drop significantly as a result. These programs could be eliminated in their entirety at the federal level, saving \$337 billion (OMB, 2012), and with the burden of Medicaid lifted from the states, these programs with their resulting reduced costs could be transferred to the states, with the idea that states could adopt or reject individual programs, or experiment with new approaches.

The net cost of this health care plan is thus approximately $\$ 100$ billion at the federal level. This approach to health care and welfare spending is conceptually based on the federalism principle - the federal government provides a baseline safety net, and states are free to supplement as they see fit. 
To see how this would work in practice, let us consider the impact on specific individuals. Table 11 shows the current interaction of taxes and welfare payments for a family of three as they progress from $\$ 15,000$ to $\$ 55,000$ in annual earned income (author's calculations, based upon data for Texas, plus state taxes assumed at a flat rate of $5 \%$ :

Table 11 - "Welfare Trap" Impact Of Welfare And Taxes On Families

\begin{tabular}{|l|r|r|r|r|r|r|}
\hline Earned Income & $\$ 5,000$ & $\$ 15,000$ & $\$ 25,000$ & $\$ 35,000$ & $\$ 45,000$ & $\$ 55,000$ \\
\hline FICA & $(383)$ & $(1,148)$ & $(1,913)$ & $(2,678)$ & $(3,443)$ & $(4,208)$ \\
\hline Federal income tax & 0 & 0 & $(570)$ & $(2,100)$ & $(3,531)$ & $(4,987)$ \\
\hline State income tax & $(250)$ & $(750)$ & $(1,250)$ & $(1,750)$ & $(2,250)$ & $(2,750)$ \\
\hline EITC & 2,000 & 5,028 & 3,218 & 1,108 & 0 & 0 \\
\hline Food stamps & 6,312 & 4,733 & 1,443 & 0 & 0 & 0 \\
\hline Medicaid/SCHIP & 15,000 & 15000 & 15,000 & 6,000 & 6,000 & 0 \\
\hline Section 8 housing & 7,500 & 4,500 & 1,500 & 0 & 0 & 0 \\
\hline TANF & 4,740 & 4,740 & 0, & 0 & 0 & 0 \\
\hline Net economic benefit & 40,302 & 48,251 & 44,341 & 38,258 & 45,219 & 47,263 \\
\hline
\end{tabular}

This "welfare trap" or "poverty trap" phenomenon, whereby increased taxes and lost welfare benefits essentially offset additional earned income dollar-for-dollar, amounts to an effective tax rate of $100 \%$ and serves as a considerable disincentive for persons with low incomes to seek jobs (or better-paying jobs for those who have jobs). Thies (2009) found results very similar to the above for a family of three in Virginia, as noted in Mankiw (2009). Clearly any "means tested" welfare program must inherently contain points of diminishing returns. As Mankiw notes, when multiple income-related programs are piled on top of one another, the implicit marginal tax rate can exceed 100 percent. The math simply cannot work otherwise. That makes the current welfare/tax combination extremely regressive in the lower income range.

Table 12 shows how this "welfare trap" effect would essentially be eliminated with the Prebate and Bismarck health care. This table assumes that the "means tested" welfare programs would be transferred to the states, as discussed above, and has assumed that the state being portrayed has continued food stamps but has eliminated or raised the threshold for other programs. Food stamps are retained because it is assumed that 1) the more conservative states will continue fewer programs, 2) the more rural states tend to be more conservative, and 3) farmers generally support food stamps because higher demand increases crop prices.

Table 12 - Status Of Family Of Three On Welfare With Proposed Taxes And Prebate

\begin{tabular}{|l|r|r|r|r|r|r|}
\hline Earned Income & $\$ 5,000$ & $\$ 15,000$ & $\$ 25,000$ & $\$ 35,000$ & $\$ 45,000$ & $\$ 55,000$ \\
\hline Prebate & 7,500 & 7,500 & 7,500 & 7,500 & 7,500 & 7,500 \\
\hline Health care benefit & 10,800 & 10,800 & 10,800 & 10,800 & 10,800 & 10,800 \\
\hline Payroll tax & $(375)$ & $(1,125)$ & $(1,875)$ & $(2,625)$ & $(3,375)$ & $(4,125)$ \\
\hline Consumption tax & $(3,095)$ & $(4,344)$ & $(5,592)$ & $(6,841)$ & $(8 ., 090)$ & $(9,339)$ \\
\hline State tax & $(250)$ & $(750)$ & $(1,250)$ & $(1,750)$ & $(2,250)$ & $(2,750)$ \\
\hline Subtotal & 19,580 & 27,081 & 34,583 & 42,084 & 49,585 & 57,086 \\
\hline $\begin{array}{l}\text { Assume state continues food } \\
\text { stamps }\end{array}$ & 6,312 & 4,733 & 1,443 & & 0 & 0 \\
\hline Total & 25,892 & 31,814 & 36,026 & 42,084 & 49,585 & 57,086 \\
\hline
\end{tabular}

Two particular things which should be noted in this calculation are that 1) with nothing more than a single minimum-wage job, the hypothetical family of three is above the poverty line (and while not included here to save space, analyses of other individual and family situations reveal this to be true in every case), and 2) the disincentives to seek work, or a better job, have been almost entirely removed. Our hypothetical family of three is somewhat better off under the current system up to $\$ 25,000$ earned income; but at $\$ 35,000$ and above, clearly better off with the Prefund/Bismarck health care combination. This turns what may be described as a handout today into a "hand up." At $\$ 55,000$, the illustrated family is roughly $\$ 10,000$ better off than today, and would incur taxes above that point at essentially a marginal tax rate of $30 \%$ (15\% payroll/business profits plus $15 \%$ consumption), obviously making the middle class better off as well. 
Another feature for consideration is adoption of the Swedish "no fault" medical malpractice system. This operates somewhat like US workers' compensation now; damaged parties get faster compensation through a review board, without the jackpot damage awards given by some US juries and courts.

\section{REFORM OF MANDATORY PROGRAMS}

Above and beyond the changes to the health and welfare programs discussed above, there are also some efficiency improvements that can be made to mandatory programs such as Medicare which will remain. Edwards (2005) has identified the following changes to Medicare with estimated annual impact in 2015 totaling $\$ 77$ billion:

- $\quad$ Increase Medicare Part B premiums to cover 50\% of program costs - $\$ 59$ billion

- Increase and conform deductibles for Medicare Parts A and B and medigap policies - $\$ 18$ billion

\section{DEFENSE SPENDING}

Defense spending currently comprises almost $20 \%$ of total federal spending, and roughly half of discretionary spending. Clearly, some cuts in defense will be required to achieve a balanced budget. The goal should be to cut in areas that minimize the negative impact on national security. The following changes are proposed as fulfilling that requirement:

- $\quad$ Military personnel cost approximately $\$ 125$ billion per year. The way to have a strong military force without excessive cost is to keep a substantial portion of that military force at a lowered state of readiness (Luttwak, 1985, p. 211-212). This principle is applied quite successfully by nations such as Israel, Sweden, and Switzerland, who maintain large and capable military forces for a reduced cost by relying heavily on reserve components. The US could employ this principle to maintain a much larger and more capable force that would be available in time of war for a reduced cost in time of peace. Reservists serve part-time and are typically paid for approximately 60 days per year, or one-sixth as much as conventional soldiers, sailors, airmen, and Marines. They also incur lower operating costs per capita. Analysis of detailed budget line item data for the period 2013-15 indicate that payroll cost for roughly 1.45 million active duty military personnel is approximately $\$ 83,000$ per capita, while the corresponding cost for roughly 850,000 reservists is approximately $\$ 25,000$ per capita. In terms of personnel costs, converting about 450,000 active duty slots (costing about $\$ 37$ billion annually) to 950,000 reserve slots (costing about $\$ 23$ billion annually) would save $\$ 14$ billion annually (approximately $11 \%$ of current personnel costs), while raising potential end strength from 2.3 million (1.45 million active and 850,000 reserves) to 2.8 million (1 million active and 1.8 million reserves). An added benefit would be that the smaller standing army would provide less temptation to political leaders to become ensnared in every dispute worldwide.

- $\quad$ Operation and maintenance (O\&M) costs approach $\$ 300$ billion per year. One way to reduce the need for a peacetime standing army is to bring home most if not all the 250,000 troops currently deployed overseas at roughly 1,000 bases in Germany, Japan, and other locations. If some presence is still desired, active duty troops on site could be replaced by much cheaper reserve troops who would be activated and deployed only in an emergency. In 2004 Defense Secretary Rumsfeld estimated that closing 200 to 300 of those bases could save $\$ 12$ billion annually (Vine, 2011). Considering inflation, it is reasonable to conclude that closing substantially all of those bases should generate an O\&M cost savings roughly comparable to the $11 \%$ personnel cost savings, or approximately $\$ 30$ billion per year given current operation and maintenance expenditure levels.

- $\quad$ Annual expenditure on new weapons systems approximates $\$ 200$ billion per year, including approximately $\$ 125$ billion procurement and $\$ 75$ billion research and development. Various analysts have proposed procurement cuts ranging from $\$ 10$ billion (Edwards, 2005) to $\$ 50$ billion per year. One generally accepted problem is that defense procurement tends to be weighted unreasonably heavily toward costly state-of-the-art systems, when in many cases a cheaper solution would serve as well. For example, the Navy is using Arleigh Burke class Aegis destroyers on pirate patrol in the Indian Ocean when much cheaper Knox or Perry class frigates (or versions of European frigates or Coast Guard cutters) could do the job as well or better. Even worse, in many cases the expensive systems have failed to meet specifications, even after costly modifications. A solution would be to implement the high/low procurement procedures 
employed by former Chief of Naval Operations Elmo Zumwalt. This could include more state of the art (first rate) procurement for active forces and more second rate items for reserves and foreign sales. Another way to cut procurement costs would be to combine procurement of many items with NATO and other treaty partners to reduce costs for all parties. The target for procurement savings could be slightly higher than the personnel and O\&M savings, or 15\% per year for a reduction of $\$ 30$ billion per year.

- $\quad$ Cut another $\$ 20$ billion through efficiency savings per year through measures identified by Secretary of Defense Robert Gates (Wilson, 2010).

- $\quad$ A reduction in defense contractors by $15 \%$ would save another $\$ 7$ billion per year (Coburn 2011).

- $\quad$ Get rid of top-heavy management structure (Luttwak 1985) with unspecified savings.

Assuming all of these changes are phased in over time, the impact on defense spending for the first year, first five years, and first ten years can be estimated as shown in Table 13:

Table 13 - Proposed Changes To Defense Spending

\begin{tabular}{|l|c|c|c|c|}
\hline \multicolumn{1}{|c|}{$\begin{array}{c}\text { Step } \\
\text { (amounts in billions of dollars) }\end{array}$} & $\begin{array}{c}\text { Annual (2013 } \\
\text { dollars) }\end{array}$ & \multicolumn{3}{c|}{ Savings (\$ Billions) } \\
\cline { 3 - 5 } & 15 & 5 & 70 & 180 \\
\hline Convert 450,000 active duty slots to 950,000 reserve slots & 15 & 0 & 80 & 280 \\
\hline Bring troops home from overseas & 30 & 6 & 82 & 207 \\
\hline $\begin{array}{l}\text { Reduce procurement and research and development costs } \\
\text { by converting to high/low mix strategy and make other } \\
\text { procurement changes, eliminating least promising } \\
\text { technologies, and cooperating more closely with NATO } \\
\text { and other allies }\end{array}$ & 30 & & & \\
\hline Reduce size of nuclear arsenal & & & & \\
\hline $\begin{array}{l}\text { Implement efficiency savings identified by Secretary of } \\
\text { Defense Gates (2010) }\end{array}$ & 5 & 1 & 10 & 60 \\
\hline Reduce defense contractors by 15\% & 20 & 5 & 60 & 140 \\
\hline Totals & 7 & 3 & 30 & 67 \\
\hline
\end{tabular}

\section{NON-DEFENSE DISCRETIONARY SPENDING}

A number of groups have taken differing looks at possible cuts to non-defense federal spending. Where savings have been calculated by the sources for a one-year period, the costs over 5 and 10 year periods have been inflated at a rate of 3\% per year. Where the sources calculated savings based on a 10-year period, the savings for 1 and 5 years have been estimated as $6 \%$ and $45 \%$, respectively, of the 10-year amount, to reflect phasing in and inflation/growth. These savings are summarized in Table 14:

Table 14 - Proposed Changes To Non-Defense Discretionary Spending

\begin{tabular}{|c|c|c|c|c|}
\hline \multirow{2}{*}{ Source } & \multirow{2}{*}{ Description } & \multicolumn{3}{|c|}{ Estimated Savings (\$Billions) } \\
\hline & & 1 year & 5 years & 10 years \\
\hline & General Government & & & \\
\hline $\mathrm{C}, \mathrm{D}$ & Three-year freeze on federal salaries & 8 & 64 & 144 \\
\hline $\mathrm{C}, \mathrm{R}$ & Reduce federal headcount $15 \%$ through attrition & 13 & 102 & 229 \\
\hline $\mathrm{C}, \mathrm{R}$ & Reduce number of and spending for federal contractors by $15 \%$ & 13 & 104 & 233 \\
\hline $\mathrm{C}, \mathrm{R}$ & Reduce federal vehicle fleet by $20 \%$ & 0 & 2 & 6 \\
\hline $\mathrm{C}, \mathrm{R}$ & Reduce Senate and House of Representatives budgets by $15 \%$ & 0 & 2 & 4 \\
\hline \multirow[t]{2}{*}{$\mathrm{C}$} & Eliminate the Office of National Drug Control Policy & 0 & 2 & 5 \\
\hline & Department of Agriculture & & & \\
\hline $\mathrm{C}, \mathrm{D}, \mathrm{E}$ & Reduce USDA conservation programs by $60 \%$ & 3 & 20 & 48 \\
\hline $\mathrm{C}, \mathrm{D}, \mathrm{E}$ & $\begin{array}{l}\text { Reduce USDA price support payments by eliminating the } 75 \% \text { that go } \\
\text { to large corporate farmers }\end{array}$ & 3 & 20 & 48 \\
\hline \multirow[t]{2}{*}{$\mathrm{C}, \mathrm{E}$} & Cut funding for Forest Service in half & 2 & 15 & 33 \\
\hline & Department of Commerce & & & \\
\hline \multirow[t]{2}{*}{$\mathrm{C}$} & Transfer and consolidate programs at NOAA, Census Bureau & 2 & 13 & 27 \\
\hline & Department of Education & & & \\
\hline $\mathrm{C}, \mathrm{G}$ & Consolidate programs & 25 & 130 & 280 \\
\hline
\end{tabular}




\begin{tabular}{|c|c|c|c|c|}
\hline \multirow{2}{*}{ Source } & \multirow{2}{*}{ Description } & \multicolumn{3}{|c|}{ Estimated Savings (\$Billions) } \\
\hline & & 1 year & 5 years & 10 years \\
\hline \multirow[t]{2}{*}{$\mathrm{C}$} & $\begin{array}{l}\text { Eliminate mandatory Pell Grants and reform and tighten remaining } \\
\text { grant programs }\end{array}$ & 7 & 54 & 128 \\
\hline & Department of Energy & & & \\
\hline $\mathrm{C}, \mathrm{E}$ & Eliminate the Office of Energy Efficiency and Renewable Energy & 2 & 12 & 26 \\
\hline $\mathrm{C}, \mathrm{E}$ & $\begin{array}{l}\text { Consolidate the Advance Research Projects Agency-Energy into the } \\
\text { Office of Science }\end{array}$ & 1 & 5 & 11 \\
\hline $\mathrm{C}, \mathrm{E}$ & $\begin{array}{l}\text { Consolidate the Office of Environmental Management within the } \\
\text { National Nuclear Security Administration }\end{array}$ & 2 & 15 & 34 \\
\hline \multirow[t]{2}{*}{$\mathrm{C}, \mathrm{E}$} & $\begin{array}{l}\text { Reform and reduce the Office or Electricity Delivery and Energy } \\
\text { Reliability }\end{array}$ & 1 & 7 & 15 \\
\hline & Department of Health and Human Services & & & \\
\hline \multirow[t]{2}{*}{$\mathrm{C}, \mathrm{E}$} & $\begin{array}{l}\text { Consolidate the SAMHSA activities into four core programs and } \\
\text { consolidate the agency with the CDCP }\end{array}$ & 0 & 2 & 4 \\
\hline & $\begin{array}{llll}\begin{array}{l}\text { Department of } \\
\text { Administration }\end{array} & \text { Homeland } & \text { Security/Transportation } & \text { Safety } \\
\end{array}$ & & & \\
\hline \multirow[t]{2}{*}{$\mathrm{A}, \mathrm{C}, \mathrm{E}$} & Eliminate 15 programs and reduce the costs of 10 additional programs & 3 & 12 & 24 \\
\hline & Department of Housing and Urban Development & 0 & 0 & 0 \\
\hline \multirow[t]{2}{*}{$\mathrm{A}, \mathrm{C}$} & Eliminate 12 programs and reduce the cost of 7 other programs & 5 & 40 & 86 \\
\hline & Department of the Interior & & & \\
\hline \multirow[t]{2}{*}{$\mathrm{C}, \mathrm{E}$} & Eliminate 5 programs and reduce the cost of 12 additional programs & 6 & 13 & 26 \\
\hline & Department of Justice & & & \\
\hline \multirow[t]{2}{*}{$\mathrm{A}, \mathrm{C}, \mathrm{E}, \mathrm{G}$} & Eliminate or consolidate certain programs and end duplication & 3 & 15 & 35 \\
\hline & Department of Labor and Pensions & & & \\
\hline $\mathrm{C}, \mathrm{D}$ & $\begin{array}{l}\text { Replace Federal Employee Retirement System (FERS) with defined } \\
\text { contribution plan for new employees, and equalize employer-employee } \\
\text { payments for existing FERS participants }\end{array}$ & 12 & 88 & 196 \\
\hline \multirow[t]{2}{*}{$\mathrm{C}, \mathrm{D}$} & $\begin{array}{l}\text { Set Pension Benefit Guarantee Corporation premiums at a level to } \\
\text { fund liabilities fully }\end{array}$ & 1 & 7 & 16 \\
\hline & Department of State and Foreign Affairs & & & \\
\hline $\mathrm{B}$ & Reduce the overhead cost of foreign diplomatic operations & 1 & 6 & 13 \\
\hline $\mathrm{A}, \mathrm{C}$ & $\begin{array}{l}\text { Reduce the amount of voluntary contributions the UN by } \$ 2 \text { billion per } \\
\text { year }\end{array}$ & 2 & 10 & 22 \\
\hline $\mathrm{C}$ & $\begin{array}{l}\text { End foreign aid to countries with over } \$ 10 \text { billion in unpaid debt to the } \\
\text { US }\end{array}$ & 1 & 8 & 18 \\
\hline $\mathrm{A}, \mathrm{C}, \mathrm{E}$ & Reform and consolidate various foreign aid programs & 2 & 18 & 40 \\
\hline $\mathrm{C}, \mathrm{E}$ & Reduce foreign economic aid funding & 3 & 20 & 42 \\
\hline $\mathrm{C}$ & Reduce funding to the World Bank & 0 & 1 & 3 \\
\hline \multirow[t]{2}{*}{$\mathrm{C}, \mathrm{P}$} & Reduce foreign military financing & 2 & 12 & 27 \\
\hline & Department of Transportation & & & \\
\hline \multirow[t]{2}{*}{$\mathrm{C}, \mathrm{G}$} & $\begin{array}{l}\text { Eliminate duplicative and/or low-priority spending, repeal or reform } \\
\text { unnecessary mandates, and give states more flexibility }\end{array}$ & 0 & 0 & 192 \\
\hline & Department of the Treasury & & & \\
\hline \multirow[t]{2}{*}{$\mathrm{C}$} & $\begin{array}{l}\text { Eliminate the Community Development Financial Institutions Fund, } \\
\text { Office of Technical Assistance, Tropical Forest Conservation Act, and } \\
\text { Heavily Indebted Poor Countries Initiative and Trust Fund }\end{array}$ & 1 & 4 & 10 \\
\hline & Department of Veterans Affairs & & & \\
\hline $\mathrm{C}, \mathrm{P}$ & $\begin{array}{l}\text { Require the Department of Defense and Department of Veterans } \\
\text { Affairs to co-purchase drugs, achieving savings }\end{array}$ & 0 & 3 & 7 \\
\hline \multirow[t]{2}{*}{$\mathrm{C}$} & Change co-pay requirements for veterans using VA medical facilities & 0 & 3 & 6 \\
\hline & Environmental Protection Agency & & & \\
\hline \multirow[t]{2}{*}{$\mathrm{C}, \mathrm{G}$} & $\begin{array}{l}\text { Eliminate or consolidate } 8 \text { duplicative or counterproductive programs, } \\
\text { plus reform and reduce spending for } 6 \text { other programs }\end{array}$ & 2 & 15 & 34 \\
\hline & Miscellaneous & & & \\
\hline \multirow[t]{2}{*}{$\mathrm{C}$} & Auction off more of the electronic spectrum & 2 & 10 & 20 \\
\hline & Totals & 128 & 854 & 2,092 \\
\hline
\end{tabular}

Key to Sources: A=Cato (2008), B=Bowles-Simpson (2010), C=Coburn (2011), D=Domenici-Rivlin (2010), E=Edwards (2005), $\mathrm{G}=\mathrm{GAO}$ (2011), $\mathrm{P}=$ People's Budget (2011), Ross Perot (1992-93); sources are noted if they proposed the same or similar cuts to specific activities. 


\section{PRIVATIZATION}

The federal government is engaged in a number of activities that could easily be privatized and supported by user charges. They have been privatized successfully in one or more foreign countries.

- The interstate highway system could be operated as a system of national toll roads. Estimates are that it could generate a profit of $\$ 25-50$ billion a year, after operating expenses and the $\$ 40$ billion in annual capital expenditures currently budgeted.

- $\quad$ The postal service has been privatized successfully in many locations, including New Zealand where it is combined with a bank.

- $\quad$ The air traffic control system needs substantial modernization which has not been forthcoming as rapidly as needed. Canada has avoided this problem by privatizing its system.

- $\quad$ Many European countries have privatized their formerly nationalized rail systems, and operated them more efficiently in that mode. Privatizing Amtrak could accomplish the same for the US.

- $\quad$ The Tennessee Valley Authority and the western power and water authorities currently provide service at below market prices which encourages overconsumption. If privatized they could charge market rates, fostering conservation, and could also be vehicles for alternative energy projects on a major scale.

- $\quad$ The Bureau of Reclamation and the civilian operations of the Army Corps of Engineers provide services for which they could charge market value to users if privatized.

Table 15 shows the annual savings that could be realized if these activities were privatized here and supported wholly by user charges:

Table 15 - Budget Impact Of Proposed Privatization Possibilities

\begin{tabular}{|l|l|c|}
\multicolumn{1}{|c|}{$\begin{array}{c}\text { Activity } \\
\text { (source of cost data) }\end{array}$} & \multicolumn{1}{|c|}{$\begin{array}{c}\text { Where Currently } \\
\text { Privatized Successfully }\end{array}$} & $\begin{array}{c}\text { Annual Budget } \\
\text { Cost/Subsidy (\$Billions) }\end{array}$ \\
\hline $\begin{array}{l}\text { Interstate highway system (national toll road system) (OMB, } \\
\text { 2012) }\end{array}$ & Europe & 40.5 \\
\hline Postal service (Edwards, 2005) & New Zealand & -4.7 \\
\hline Air traffic control system (Edwards, 2005) & Canada, UK & 2.8 \\
\hline Amtrak (Edwards. 2005) & Europe & 1.3 \\
\hline TVA (OMB, 2012) & UK, Brazil, Argentina, Australia & 0.0 \\
\hline Western Power and Water Authorities (Edwards, 2005) & UK, Brazil, Argentina, Australia & 0.2 \\
\hline Army Corps of Engineers civilian projects (Edwards, 2005) & UK, Brazil, Argentina, Australia & 4.9 \\
\hline Bureau of Reclamation (Edwards, 2005) & UK, Brazil, Argentina, Australia & 1.2 \\
\hline Net Annual Savings & & 46.2 \\
\hline
\end{tabular}

Over ten years, these savings of $\$ 46$ billion per year, plus the cumulative $\$ 2.1$ trillion savings on discretionary programs outlined above, produce total cumulative savings of over $\$ 2.5$ trillion in discretionary programs. In addition to saving budgetary expenditures in future years, privatization of these activities would allow more effective management processes to be implemented. Additional functions that could be supported by user fees instead of taxes could also be privatized.

One possibility would be to transfer the assets associated with these activities to the social security fund in payment of debts owed. These activities could then be set up to earn a 5\% annual return on investment (ROI), to be paid to social security trust fund to help amortize future social security costs. In this model, future investment in facilities and other assets would come from earnings and social security contributions, not from the general budget

\section{SOCIAL SECURITY}

Although the Social Security Trust Fund (Fund) is not technically insolvent at the present time, there are legitimate worries about its future. It has been estimated that social security payments would exceed tax revenues by 2017 , and that the social security fund would be depleted by 2042. In fact, the point where payments exceed revenues has been reached, bringing about expectations that the fund will not last until the 2042 date. The shortfall between 2016 and 2083 has been estimated to be as much as \$7.7 trillion (John, 2010) Former President Bill 
Clinton's 2000 budget noted that the Fund "balances are available to finance future benefit payments and other Trust Fund expenditures - but only in a bookkeeping sense... They do not consist of real economic assets that can be drawn down in the future to fund benefits" (Cato, 2005, p. 49). President Clinton himself has observed that the only ways to keep Social Security solvent are to 1) raise taxes, 2) cut benefits, or 3) get a higher rate of return through private investment. Henry Aaron of the Brookings Institute testified before Congress in 1999, "Increased funding to raise pension reserves is possible only with some combination of additional tax revenues, reduced benefits, or increased investment returns from investing in higher yield assets: (Cato, 2005, p. 50). The following changes are estimated to be sufficient to make the Trust Fund secure for at least the next 100 years, and in all likelihood forever:

- $\quad$ Remove the wage/salary cap on taxes, as noted above in the discussion of the payroll tax. This step has been estimated variously to lengthen the life of the trust fund by 30 to 70 years.

- $\quad$ Like most of Europe, combine old age, survivors, disability, and unemployment compensation into a single omnibus social security program. The payroll tax funding already described produces roughly $\$ 20$ billion per year more in revenue than the current combined federal revenues for all those purposes, which will then extend the life of social security. Adding these other programs reduces slightly the long-term effect of the tax increase above, but it is reasonable to assume that the net impact of the two steps together would add 20 to 30 years to the life of the trust fund.

- $\quad$ Raise the standard retirement age by one month per year until it reaches age 70 . Over a period of 48 years, this would phase in a significant cost reduction, consistent with rising life expectancies. For people who seek early retirement, keep the same early retirement ages, with benefits actuarially adjusted in a manner similar to the current procedure.

- $\quad$ Reduce inflationary costs by adopting a slower rate of inflationary growth on the upper end of social security benefit payments; this leaves the most needy still getting inflation protection at current rates, but gradually reduces cost by reducing payments to those best able to absorb them. This would narrow the gap between the highest and lowest social security benefits payments, with the eventual result that all recipients would receive the same amount, thus eliminating the regressive nature of the present benefits structure. CBO data indicate that indexing the entire benefit stream would save roughly $\$ 30$ billion by 2020 , and the author estimates that this approach should have an impact equal to some significant portion of that number.

- $\quad$ Restore the non-taxability of all social security benefit payments. This would help the neediest who seek work to augment social security, as well as reduce the impact of those on the upper end whose inflationary increases have been curtailed by the previous step.

- Adopt Swedish partial privatization to create "super 401k" to provide all with an investment stream of income; this will further offset the slowdown in inflationary increases to upper level social security payments. Under this approach, an employee would contribute an extra $2.5 \%$ of salaries and wages, matched by employer, to fund which would then invest in safe private sector investments. The privatized federal functions discussed previously could be one target for such investments, to provide a stable base with a guaranteed 5\% ROI. A reasonable approach would be that for each individual, the first $\$ 50,000$ in his/her account would go to these privatized government corporations, the second $\$ 50,000$ would go to a predesignated and very secure private sector investment fund, and any amounts above that could be directed to one of a number of private investment funds. This retirement account would be property of the individual. Withdrawal of proceeds would be nontaxable, so long as certain statutory provisions were observed. Upon death of an individual, the balance could be transferred to heirs.

- $\quad$ Recognize statutorily that each individual does have a property right in at least the privatized portion of his/her social security account. Further recognize the same statutory right in the trust fund portion of the account, reversing the holding in Flemming v. Nestor (1960).

With the privatized "super $401 \mathrm{k}$ " in place, each employee would take home $90 \%$ of his/her wages/salary in each paycheck, with 5\% going to a retirement account which he/she would own. Excluding the benefit from the private retirement account, the economic benefit calculations shown in Table 12 above should be revised as follows: With $\$ 5,000$ earned income the resulting economic benefit is $\$ 25,767$; with $\$ 15,000$ earned income the benefit is $\$ 31,439$; with $\$ 25,000$ earned income the economic benefit is $\$ 35,401$; with $\$ 35,000$ earned income the economic benefit is $\$ 42,209$; with 45,000 earned income the economic benefit is $\$ 48,460$; and with $\$ 55,000$ earned income the economic benefit is $\$ 55,711$. 


\section{SUMMARY}

The projected one-year impact of these proposed changes are summarized in Table 16.

Table 16 - Summary Of Impact Of Proposals

\begin{tabular}{|l|c|}
\hline \multicolumn{1}{|c|}{ Table 16 - Summary Of Impact Of Proposals } & Annual Impact (\$ Billions) \\
\hline Start with President Obama's Budget Deficit for 2013 as baseline & $(901)$ \\
\hline Increased revenues from 15-15-15 plan, net of Prebate, plus gasoline tax & 325 \\
\hline Net cost of Bismarck universal health care & 77 \\
\hline Reform of mandatory programs & 107 \\
\hline Defense savings & 340 \\
\hline Non-defense discretionary savings & 30 \\
\hline Net interest savings & $(122)$ \\
\hline Resulting budget surplus (deficit) & \\
\hline
\end{tabular}

It is expected that normal growth will eliminate the remaining deficit. Because the various steps are planned to be phased in over time, the full impact does not occur in the first year, and changes should be estimated over ten years. Table 18 summarizes the resulting budgets for the period 2013-2022, in the format of Tables S-1 and S-2 of President Obama's 2013 Budget for comparison. Highlights include:

- Debt in 2022

- $61.8 \%$ of GDP (55.4\% held by general public)

- Annual budget as a percent of GDP

- $\quad$ Revenues $-21.1 \%$ (taxes $19.3 \%$ of GDP)

- Expenditures - $20.6 \%$

- Composition of tax revenues (no individual income tax)

- $30.2 \%$ payroll tax

- $31.8 \%$ consumption tax

- $22.7 \%$ business/investment income tax

- $7.1 \%$ excise taxes

- $8.2 \%$ other

Comparing the results of this analysis to the stated goals reveals the following:

- $\quad$ Reduce annual deficit by $80-100 \%$

- $\$ 901$ billion to $\$ 122$ billion, with growth and additional measures balancing budget over time

- $\quad$ Reduce accumulated debt from $100 \%$ to $60 \%$ of GDP in 10 years

○ $61.8 \%$ in 2022 (55.4\% held by general public)

- $\quad$ Make US more competitive in world markets to increase jobs and growth

- Top corporate/business tax rates reduced below OECD average, consumption tax incorporated tariff on imports/rebate on exports, and employers relieved of significant health care costs.

- $\quad$ Maintain or improve welfare safety net

- Prebate and universal health care provide more comprehensive safety net or floor, with a single minimum wage job sufficient to put every individual and family above the poverty threshold.

- $\quad$ Maintain strongest defense in world, tailored to threat scenario

○ Resulting force more responsive to defending against actual threats

- $\quad$ Provide for future solvency of social security

- Revenues increased by eliminating the regressive wage/salary cap, future costs reduced by raising retirement age gradually and reducing inflation adjustments for wealthier retirees, ROI improved from privatized government functions and "Super 401k" created with privatized portion of accounts 


\section{OPTIONAL OR ALTERNATIVE ITEMS}

The following optional items could be adopted to eliminate any remaining deficit or generate a surplus:

- $\quad$ Raise taxes on alcohol and tobacco to cover $100 \%$ of society's cost of treatment for those suffering illness/injury as a result - possible yield $\$ 50$ billion per year

- $\quad$ Providing legal guest worker status for more immigrants, reducing current enforcement costs and generating permit fees - possible yield $\$ 1-2$ billion, plus reducing enforcement costs $\$ 50$ - 80 billion

- $\quad$ Increasing other excise taxes

- $\quad$ Establishing or raising user fees for more federal services

- $\quad$ Adjusting the tax rate from $15 \%$, higher or lower, as needed.

Alternatively, higher growth rates may take care of this remainder. Although no study of growth rates under this specific approach has been made, it can be inferred from analyses of similar approaches that the impact on growth would be favorable. This proposal includes elements of the Fair Tax and Flat Tax proposals, for which growth impacts have been forecast. With respect to the Fair Tax:

- $\quad$ Kotlikoff and Jokisch (2005) estimated that by 2030, capital stock value would be $30 \%$ higher than under current law, interest rates would be 150 basis points lower, and marginal labor productivity would increase by $18.9 \%$ and real wages by $10.6 \%$, resulting in overall economic welfare gains of $26.7 \%$ for low-income, $10.9 \%$ for middle-income, and $4.7 \%$ for high-income households.

- $\quad$ Arduin, Laffer \& Moore (2005) estimated that investment would be 33\% higher in the first year and $41 \%$ higher in the tenth year than under current law.

- $\quad$ Long-term increase in GDP has been estimated by Auerbach (1996) at 9.7\%, by Boskin (1995) at 10\%, by Jorgenson (1996) at 9-13\%, by Kotlikoff (1993) at 7-14\%, by Arduin, Laffer \& Moore (2005) at 24.4\%, and by Robbins and Robbins (1994) at 36.3\%.

- $\quad$ The Joint Committee on Taxation (1997) summarized results from nine different economic models, all of which estimated that a flat consumption tax would increase investment and economic growth.

Fair Tax advocates conducted all those studies except the last, but all appear to have followed reasonable methodologies and utilized reasonable assumptions, and there have been no studies from a different perspective to refute those results. Because this approach incorporates some Fair Tax concepts, it seems reasonable and consistent with those findings to conclude that the 15-15-15 tax plan could be expected to add something in the range of $1 \frac{1}{2} \%$ to $1 \%$ to annual growth, above what would otherwise be expected. This potential positive impact has not been considered in any of the projections herein.

Possible alternatives for consideration could include (impacts calculated by the author based upon data from IRS, 2012, Tax Statistics):

- $\quad$ Retain the individual income tax, with or without substantial reductions or eliminations of deductions or modification of taxable income calculations. The impact of this change would vary depending upon what definition of taxable income was used, what exemptions/deductions are retained, and whether the Prebate was adjusted to offset the income tax as well as other taxes. If essentially all current itemized deductions and exemptions were eliminated, and the individual income tax were applied to what is currently defined as Adjusted Gross Income (AGI), the required flat rate for all taxes in the package (payroll, consumption, business, and individual income) to be revenue neutral would drop from $15 \%$ to $12.3 \%$ (if the Prebate rate is kept at $30 \%$ ) or $13.2 \%$ (if the Prebate rate is increased to offset all three taxes). If the individual income tax were applied to Taxable Income as currently defined, the respective rates would be approximately $13.3 \%$ with the Prebate rate at $30 \%$ and $14.7 \%$ with the Prebate rate increased. Retention of some, but not all, exemptions and deductions would produce a rate somewhere between those two extremes.

- $\quad$ Retain the individual income tax with a more progressive tax structure. If the top marginal rates for individuals were raised to the $27 \%$ level generally proposed by Bowles-Simpson and Rivlin-Domenici, and applied to all taxable income above $\$ 200,000$, this would generate an additional $\$ 100-200$ billion in annual revenues. That revenue could be used to reduce taxes in other areas. 


\section{CONCLUSION}

This paper outlines one approach to balancing the US federal budget, eliminating the annual budget deficit, and ultimately reducing the outstanding federal debt. The intent is not to state that this is the only way, or even the best way, to get it done, but to show that there are ways that it can be done and to serve as a starting point for further discussion and consideration. It does appear that any solution to the problem must include:

- Increased tax revenues

- $\quad$ Reform of health and welfare programs to reduce cost

- $\quad$ Reductions to military spending

- $\quad$ Reductions to non-military discretionary spending

\section{AUTHOR INFORMATION}

Dr. Matthews is Assistant Professor of Business Administration at Sam Houston State University. He received a J.D. from the University of Houston Law Center, and a B.A. in Math and Economics and a M. of Accounting from Rice University. He is licensed in Texas as an Attorney at Law and a Certified Public Accountant. E-mail: $\underline{\text { RBM003@SHSU.EDU }}$

\section{REFERENCES}

1. Arduin, Laffer \& Moore Econometrics, Dec 2005, “A Macroeconomic Analysis of the Fair Tax Proposal," Washington, DC, USA: Americans for Fair Taxation Research Monograph.

2. Auerbach, Alan, 1996, "Tax Reform, Capital Allocation, Efficiency, and Growth," in Economic Effects of Fundamental Tax Reform (H. Aaron and W. Gale, editors), Washington, DC, USA: Brookings Institution Press, p. 58.

3. Bachman, Paul, J. Haughton, L. J. Kotlikoff, A. Sanchez-Penalver, and D. G. Tuerck, 13 Nov 2006 , "Taxing Sales Under the Fair Tax: What Rate Works?" Tax Analysts Special Report, accessed 11 Dec 2012 at http://www.fairtax.org/PDF/Tax\%20Notes\%20article\%20on\%20FT\%20rate.pdf

4. Bloomberg, Michael, 8 Nov 2011, untitled speech to Center for American Progress and the American Action Forum at the Center for American Progress.

5. Boortz, Neal, and J. Linder, 2006, The Fair Tax Book: Saying Goodbye to the Income Tax and the IRS, New York, NY, USA: HarperCollins.

6. Boortz, Neal, J. Linder, and R. Woodall, 2008, Fair Tax: The Truth, New York, NY, USA: HarperCollins.

7. Bowles, Chester, and Alan Simpson (co-chairs), December 2010, "Moment of Truth: Report of the National Commission on Fiscal Responsibility and Reform," Washington, DC, USA: National Commission on Fiscal Responsibility and Reform.

8. Burke, Michael, June 6, 1995, “A Framework for the Tax Reform Debate," testimony before the House Ways and Means Committee.

9. Burke, Patrick, 8 Aug 2012, “CBO: Obamacare Will Leave 30 Million Uninsured,” cnsnews.com, accessed 20 Dec 2012 at http://cnsnews.com/news/article/cbo-obamacare-will-leave-30-million-uninsured

10. Cato Institute, 2005, Cato Handbook on Policy, Washington, DC, USA.

11. Cato Institute, 2008, Cato Handbook for Policymakers, Washington, DC, USA.

12. Coburn, Tom, July 2011, "Back in Black: A Deficit Reduction Plan," accessed 21 December 2012 at http://www.coburn.senate.gov/public/index.cfm/back-in-black-a-deficit-reduction-plan?p=deficit-reduction

13. Congressional Progressive Caucus, 2011, "The People's Budget: Budget of the Congressional Progressive Caucus - Fiscal Year 2012," accessed 20 November 2012 at http://cpc.grijalva.house.gov/index.cfm?sectionid=70\&sectiontree=5,70.

14. Dale, Laura, 16 Mar 1998, "Comments on William Gale’s paper entitled "An Evaluation of a National Sales Tax", February 17, 1998 and "Don't Buy the Sales Tax" (Policy Brief no. 31)," memorandum to David Burton \& Dan Mastromarco.

15. Domenici, Peter, and Alice Rivlin (co-chairs), Nov 2010, "Restoring America's Future: Reviving the Economy, Cutting Spending and Debt, and Creating a Simple, Pro-Growth Tax System,” Washington, DC, USA: Bipartisan Policy Center. 
16. Edwards, Chris, 2005, Downsizing the Federal Government, Washington, DC, USA: Cato Institute.

17. Elmendorf, Douglas W. (Director, CBO), 18 Nov 2009, letter to Hon. Harry Reid, Senate Majority Leader.

18. Elmendorf, Douglas W. (Director, CBO), 19 Dec 2009, letter to Hon. Harry Reid, Senate Majority Leader.

19. Elmendorf, Douglas W. (Director, CBO), Jul 2012, "Estimates for the Insurance Coverage Provisions of the Affordable Care Act Updated for the Recent Supreme Court Decision," Washington, DC, USA: Congressional Budget Office.

20. $\quad$ Flemming v. Nestor, 1960, 363 U.S. 603.

21. Friedman, Milton, 1962, Capitalism and Freedom, Chicago, IL, USA: University of Chicago Press.

22. Gale, William, 17 Feb 1998, "An Evaluation of a National Sales Tax," Washington, DC, USA: The Brookings Institute.

23. Gale, William, 16 May 2005, "The National Sales Tax: What Would the Rate Have to Be?" Washington, DC, USA: Tax Analysts.

24. Gaver, John, 5 Oct 2010, “1986-2008 IRS Collections Data by Income Category (Percentile),” Action America, accessed 22 Dec 2012 at http://ActionAmerica.org/taxecon/irsdata.shtml

25. General Accounting Office, Mar 2011, Opportunities to Reduce Potential Duplication in Government Programs, Save Tax Dollars, and Enhance Revenue, Washington, DC, USA: GAO-11-318SP.

26. Hoagland, Ken, 2010, The Fair Tax Solution: Financial Justice for All Americans, New York, NY, USA: Penguin Group.

27. Internal Revenue Service, 2012, "Tax Statistics,” accessed 20 October 2012 at http://www.irs.gov/uac/Tax$\underline{\text { Stats-2 }}$

28. John, David C., 22 Nov 2010, "Time to Raise Social Security's Retirement Age," Washington, DC, USA: Heritage Foundation, Backgrounder \#2493, accessed 20 Nov 2012 at http://www.heritage.org/research/reports/2010/11/time-to-raise-social-securitys-retirement-age

29. Joint Committee on Taxation, 20 Nov 1997, "Tax Modeling Project and 1997 Symposium Papers," JCS21-97.

30. Jorgenson, Dale W., Nov 1996, "The Economic Impact of the National Sales Tax."

31. Kendall, David, and Jim Kessler, Sep 2010, "Growth, not Greece: A Growth-Focused Deficit Reduction Agenda," Washington, DC, USA: Third Way.

32. Kotlikoff, Laurence J., 15 Apr 1993, "The Economic Impact of Replacing Federal Income Taxes with a Sales Tax," Washington, DC, USA: Cato Institute Policy Analysis No. 193.

33. Kotlikoff, Laurence J., Dec 1996, "Replacing the U.S. Federal Tax System with a Retail Sales TaxMacroeconomic and Distributional Effects," report to Americans for Fair Taxation.

34. Kotlikoff, Laurence J., and S. Jokisch, Dec 2005, "Simulating the Dynamic Macroeconomic and Microeconomic Effects of the Fair Tax," Washington, DC, USA: National Bureau of Economic Research, Working Paper No. 11858.

35. Luttwak, Edward N., 1985, The Pentagon and the Art of War, New York, NY, USA: Simon \& Schuster, Inc.

36. Mankiw, Greg, 11 November 2009, “The Poverty Trap,” accessed 11 Jan 2012 at http://gregmankiw.blogspot.com/2009/11/poverty-trap.html

37. Mencarow, W. J., 9 September 2011, "Do The Rich Pay Their "Fair Share" Of Taxes? No, They Pay A Lot More. Over Half The Adult Population Pays No Income Tax At All - And Many Of Those Get Refunds!" The Paper Source, accessed 11 Dec 2012 at http://papersourceonline.com/2941/do-the-rich-pay-their-fairshare-of-taxes-no-they-pay-a-lot-more/

38. Obama, Barack H., and Office of Management and Budget (OMB), 2012, "Budget of the United States Government 2013," Washington, DC, USA: Government Printing Office, accessed 20 Sep 2012 at http://www.gpo.gov/fdsys/browse/collectionGPO.action?collectionCode=BUDGET

39. Organisation for Economic Co-operation and Development (OECD), 2008, "Growing Unequal? Income Distribution and Poverty in OECD Countries," Paris, France.

40. Organisation for Economic Co-operation and Development (OECD), 2012, "Tax Database," Paris, France, accessed 20 Sep 2012 at http://www.oecd.org/tax/

41. Perot, Ross, 1992, United We Stand: How We Can Take Back Our Country, New York, NY, USA: Hyperion.

42. Perot, Ross, 1993, Not For Sale At Any Price: How We Can Save America for Our Children, New York, NY, USA: Hyperion. 
43. Robbins, Gary and Aldona, 1 Sep 1994, "Looking Back to Move Forward: What Tax Policy Costs Americans and the Economy," Washington, DC, USA: Institute for Policy Innovation, Policy Report No. 127.

44. Romney for President, 2012, "Mitt and Ann Romney, Individual Income Tax Return, Form 1040," accessed 20 Sep 2012 at http://c4230422.r22.cf2.rackcdn.com/1040-2010.pdf

45. Smith, Donna, and Richard Cowan, 1 Nov 2011, "No deal by U.S. deficit panel would be dire: experts," Reuters, accessed 27 Jan 2012 at http://www.reuters.com/article/2011/11/01/us-usa-debt-supercommitteeidUSTRE7A06AQ20111101

46. Tax Policy Center, 2012, "Tax Facts," accessed 20 Sep 2012 at http://taxpolicycenter.org/TaxFacts/listdocs.cfm?topic2id=30

47. Thies, Clifford F., 9 Nov 2009, “The Dead Zone: The Implicit Marginal Tax Rate,” Auburn, AL, USA: Ludwig von Mises Institute, accessed 20 Sep 2012 at http://mises.org/daily/3822

48. Tuerck, David, J. Haughton, P. Bachman, and A. Sanchez-Penalver, 2007, "A Comparison of the Fair Tax Base and Rate with Other National Tax Reform Proposals," Boston, MA, USA: The Beacon Hill Institute at Suffolk University.

49. Urban Institute, 21 December 2011, estimates based on data from CMS (Form 64), accessed 31 Dec 2012 at http://www.statehealthfacts.org/comparetable.jsp?ind=636\&cat=4\&sub=47\&yr=133\&typ=4

50. Vine, David, 25 February 2009, “Too Many Overseas Bases,” Foreign Policy in Focus, accessed 20 Dec 2012 at http://www.fpif.org/articles/too_many_overseas bases

51. Wilson, Elaine, 14 September 2010, “Gates Unveils Strategy to Cut Costs, Boost Efficiency,” Washington, DC, USA: Department of Defense, American Forces Press Service, accessed 20 Dec 2011 at http://www.defense.gov/news/newsarticle.aspx?id=60854

52. Woolf, Richard, 9 Jan 2012, "U.S. debt is now equal to economy," USA Today, accessed 27 Jan 2012 at http://www.usatoday.com/news/washington/story/2012-01-08/debt-equals-economy/52460208/1

53. World Health Organization, 2000, The World Health Report 2000: Health Systems: Improving Performance, Geneva, Switzerland: World Health Organization, accessed 31 Dec 2009 at www.who.int/whr/2000/en/who00_en.pdf 
Table 17 - Historic Data Used In Projections

\begin{tabular}{|c|c|c|c|c|c|c|c|c|}
\hline Item (amounts in billions, unless otherwise noted) & Source & 2005 & 2006 & 2007 & 2008 & 2009 & \% OF GDP & \% Growth \\
\hline Gross Domestic Product (GDP) & OMB & 12,623 & 13,377 & 14,029 & 14,369 & 13,939 & & $2.5 \%$ \\
\hline Population (millions) & Census Bureau & 293 & 296 & 299 & 301 & 304 & & $0.9 \%$ \\
\hline Number of family units (millions) & Census Bureau & 78 & 78 & 79 & 80 & 81 & & $0.9 \%$ \\
\hline Salaries and wages & IRS & 5,155 & 5,469 & 5,842 & 5,951 & 5,707 & $41.2 \%$ & $2.6 \%$ \\
\hline Corporation taxable income & IRS & 1,598 & 1,473 & 1,379 & 1,079 & 1,382 & $10.7 \%$ & $(3.6 \%)$ \\
\hline S Corporation taxable income & IRS & 421 & 457 & 484 & 432 & 449 & $3.3 \%$ & $1.6 \%$ \\
\hline Partnership taxable income & IRS & 724 & 871 & 976 & 929 & 874 & $6.4 \%$ & $4.9 \%$ \\
\hline Schedule $\mathrm{C}$ taxable income & IRS & 270 & 282 & 280 & 264 & 245 & $2.0 \%$ & $(2.2 \%)$ \\
\hline Rents, royalties, farming, and other taxable income & IRS & 35 & 24 & 25 & 35 & 25 & $0.2 \%$ & $(2.0 \%)$ \\
\hline Dividend income & IRS & 166 & 199 & 237 & 219 & 163 & $1.4 \%$ & $(0.5 \%)$ \\
\hline Interest income & IRS & 162 & 223 & 268 & 223 & 168 & $1.5 \%$ & $0.8 \%$ \\
\hline Capital gains & IRS & 663 & 771 & 896 & 467 & 231 & $4.4 \%$ & $(23.2 \%)$ \\
\hline
\end{tabular}

Capital gains

\begin{tabular}{l|l}
771 & 896 \\
\hline
\end{tabular}

Sources: IRS is IRS tax database; OMB is President's Budget for 2013 
Table 18 - Budget With Proposed Changes 2013-2022

\begin{tabular}{|c|c|c|c|c|c|c|c|c|c|}
\hline (Dollars in billions) & 2013 & 2014 & 2015 & 2016 & 2017 & 5-year Total & 2018-2022 & $\begin{array}{c}\text { 10-year } \\
\text { Total }\end{array}$ & $\begin{array}{l}\text { Obama 10- } \\
\text { Year Total }\end{array}$ \\
\hline Individual Income Tax & 0 & 0 & 0 & 0 & 0 & 0 & 0 & 0 & 18304 \\
\hline Consumption tax & 1838 & 1930 & 2045 & 2167 & 2292 & 10272 & 13173 & 23455 & 0 \\
\hline Less Prebate & $(839)$ & $(870)$ & $(902)$ & $(935)$ & $(963)$ & $(4509)$ & $(5365)$ & (9874) & 0 \\
\hline Payroll tax & 1345 & 1412 & 1496 & 1585 & 1677 & 7515 & 9647 & 17162 & 12667 \\
\hline Less Privatized portion & (336) & $(353)$ & (374) & (396) & $(419)$ & $(1878)$ & $(2410)$ & $(4288)$ & 0 \\
\hline Business income tax & 577 & 603 & 642 & 680 & 720 & 3225 & 4141 & 7366 & 4444 \\
\hline Investment income taxes & 181 & 190 & 202 & 214 & 226 & 1013 & 1301 & 2314 & 0 \\
\hline Excise, estate, and gift taxes & 132 & 175 & 214 & 248 & 288 & 1057 & 1992 & 3049 & 1353 \\
\hline Other receipts & 154 & 218 & 328 & 384 & 357 & 1441 & 2065 & 3506 & 3506 \\
\hline TOTAL RECEIPTS & 3052 & 3308 & 3651 & 3947 & 41778 & 18136 & 24553 & 42689 & 40274 \\
\hline Defense & 689 & 588 & 593 & 605 & 621 & 3096 & 3184 & 6280 & 7216 \\
\hline Non-defense discretionary & 396 & 324 & 321 & 324 & 331 & 1696 & 1482 & 3178 & 5680 \\
\hline Social security & 826 & 874 & 924 & 976 & 1033 & 4633 & 6100 & 10733 & 10702 \\
\hline Health care & 1331 & 1396 & 1454 & 1543 & 1600 & 7324 & 9550 & 16874 & 11493 \\
\hline Other mandatory & 196 & 179 & 179 & 188 & 187 & 929 & 1020 & 1949 & 6957 \\
\hline Net interest & 246 & 343 & 369 & 471 & 560 & 1989 & 3593 & 5582 & 5889 \\
\hline Other, net & 78 & $(14)$ & $(58)$ & $(78)$ & $(95)$ & $(167)$ & $(812)$ & $(979)$ & $(979)$ \\
\hline TOTAL OUTLAYS & 3762 & 3690 & 3782 & 4029 & 4237 & 19500 & 24117 & 43617 & 46958 \\
\hline SURPLUS (DEFICIT) & $(710)$ & $(382)$ & $(131)$ & $(82)$ & $(59)$ & $(1364)$ & 436 & $(928)$ & $(6684)$ \\
\hline OBAMA 2013 PROJECTIONS & $(901)$ & $(668)$ & $(610)$ & $(649)$ & $(613)$ & $(3441)$ & $(3243)$ & $(6684)$ & \\
\hline Total debt & 16710 & 14982 & 15256 & 15471 & 15650 & & 15744 & & 23750 \\
\hline Debt held by the public & 12825 & 13350 & 13624 & 13839 & 14018 & & 14112 & & 19486 \\
\hline GDP & 16335 & 17156 & 18178 & 19261 & 20369 & & 25488 & & 25488 \\
\hline Receipts as \% GDP & $18.7 \%$ & $19.3 \%$ & $20.1 \%$ & $20.5 \%$ & $20.5 \%$ & & $20.5 \%$ & & $19.3 \%$ \\
\hline Outlays as \% GDP & $23.0 \%$ & $21.5 \%$ & $20.8 \%$ & $20.9 \%$ & $20.8 \%$ & & $20.9 \%$ & & $22.5 \%$ \\
\hline Surplus (Deficit) as \% GDP & $(4.5 \%)$ & $(1.9 \%)$ & $(0.8 \%)$ & $(0.5 \%)$ & $(0.1 \%)$ & & $(0.4 \%)$ & & $(3.2 \%)$ \\
\hline Debt as a \% of GDP & $102.3 \%$ & $87.3 \%$ & $83.9 \%$ & $80.3 \%$ & $76.8 \%$ & & $61.8 \%$ & & $113.9 \%$ \\
\hline Debt held by public as \% GDP & $78.5 \%$ & $77.8 \%$ & $74.9 \%$ & $71.8 \%$ & $68.8 \%$ & & $55.4 \%$ & & $93.5 \%$ \\
\hline
\end{tabular}




\section{$\underline{\text { NOTES }}$}

